\title{
Timing of Palaeozoic magmatism in the Maggia and Sambuco nappes and paleogeographic implications (Central Lepontine Alps)
}

\author{
Denise Bussien • François Bussy • Tomas Magna • \\ Henri Masson
}

Received: 30 November 2009/Accepted: 1 November 2010/Published online: 16 February 2011

(C) Swiss Geological Society 2011

Editorial handling: Edwin Gnos.

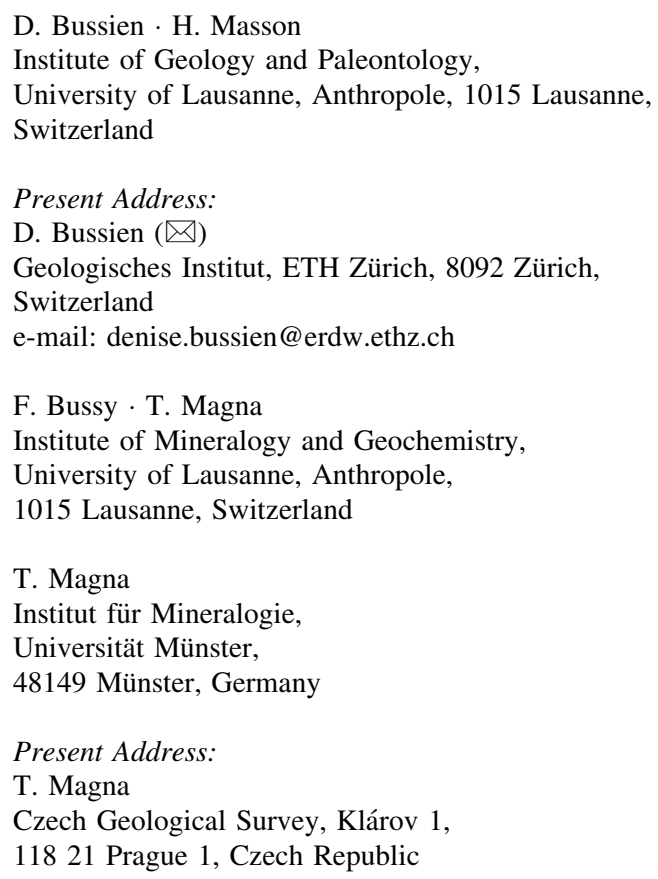

\begin{abstract}
Magmatic rocks from the pre-Mesozoic basements of the Sambuco and Maggia nappes have been dated by $\mathrm{U}-\mathrm{Pb}$ zircon ages with the LA-ICPMS technique. Several magmatic events have been identified in the Sambuco nappe. The mafic banded calc-alkaline suite of Scheggia is dated at $540 \mathrm{Ma}$, an age comparable to that of mafic rocks in the Austroalpine Silvretta nappe. The Sasso Nero peraluminous augengneiss has an age of 480-470 Ma, like many other "older orthogneisses" in Alpine basement units. It hosts a large proportion of inherited zircons, which were dated around $630 \mathrm{Ma}$, a Panafrican age indicating the Gondwanan
\end{abstract}

affiliation of the Sambuco basement. The calc-alkaline Matorello pluton yielded ages around $300 \mathrm{Ma}$, similar to numerous Late Carboniferous intrusions in other basement units of the Lower Penninic (Monte Leone, Antigorio, Verampio) and Helvetic domains (Gotthard and other External Crystalline Massifs). Associated lamprophyric dykes are slightly younger (300-290 Ma), like similar dykes sampled in gneiss blocks included in the sedimentary cover of the underlying Antigorio nappe (290-285 Ma). The Cocco granodiorite and Rüscada leucogranite, both intruding the basement of the neighbouring Maggia nappe, yielded ages of ca. 300-310 Ma, identical within errors to the age of the Matorello pluton. They are significantly older than former age determinations. This age coincidence, coupled with remarkable petrologic similarities between the Cocco and Matorello granodiorites, strongly suggests paleogeographic proximity of the Sambuco and Maggia nappes in Late Carboniferous times. In recent publications these two nappes have been interpreted as belonging to distinct Mesozoic paleogeographic domains: "European" for Sambuco and "Briançonnais" for Maggia, separated by the "Valais" oceanic basin. In this case, the similarity of the Matorello and Cocco intrusions would demonstrate the absence of any significant transcurrent movement between these two continental domains. Alternatively, according to a more traditional view, Sambuco and Maggia might belong to a single large Alpine tectonic unit.

Keywords LA-ICPMS U-Pb dating - Zircon . Granite $\cdot$ Variscan $\cdot$ Penninic $\cdot$ Swiss Alps

\section{Introduction: Paleozoic orogenies in the Central Alps}

Pre-Mesozoic geology of the Alps is recorded in the basements of the nappe stack that forms the belt. Although the 
basement history is still relatively poorly known if compared to the Mesozoic and Tertiary record, modern research based on isotopic dating and geochemistry of magmatic rocks has thrown a new light on the ancient evolution of the Alpine basement. Two major events have been documented: a Cambrian-Ordovician cycle (sometimes abusively called Caledonian), and a Variscan or Hercynian cycle of Middle Devonian to Permian age. Clues of older events have been identified in a few places, like in the Silvretta nappe (Austroalpine), where a metadiorite has been dated at $609 \pm 3 \mathrm{Ma}$ and a gabbro-tonalite calc-alkaline series at ca. $525 \mathrm{Ma}$, interpreted as evidence for an island-arc setting (Schaltegger et al. 1997).

The Cambrian-Ordovician orogenic cycle starts with ca. $500 \mathrm{Ma}$ old A-type alkaline granites attributed to continental rifting, recorded in the Briançonnais domain (Guillot et al. 1991; Bussy et al. 1996) and in the Silvretta nappe (Austroalpine domain; Müller et al. 1995). A complete collisional sequence is documented in the Aar massif, with early HP metamorphism affecting a gabbro protolith formed at $478 \pm 5 \mathrm{Ma}$, Barrovian metamorphism and decompression partial melting at ca. $450 \mathrm{Ma}$ (Schaltegger et al. 2003). Bodies of peraluminous and calc-alkaline orthogneisses of similar age (480-450 Ma) are ubiquitous in the basements of all paleogeographic domains, attesting the wide extension of this orogeny (e.g. Bussy and von Raumer 1994; Poller et al. 1997; Schaltegger and Gebauer 1999; Bertrand et al. 2000; Guillot et al. 2002).

Variscan relics are even more widespread and particularly well preserved in the External Crystalline Massifs of the Alpine belt (e.g. Aar, Gotthard, Aiguilles-Rouges and MontBlanc). Early and still undated mafic eclogites are preserved in the Lake Cornu area (Aiguilles-Rouges; Liégeois and Duchesne 1981; von Raumer and Bussy 2004). Nappe stacking led to Barrovian metamorphism (U-Pb monazite ages of $327 \pm 2 \mathrm{Ma}$ in the Aiguilles-Rouges, Bussy et al. 2000; and 317.5 $\pm 2 \mathrm{Ma}$ in the Aar, Schaltegger et al. 2003) and partial melting (U-Pb monazite age of $321 \mathrm{Ma}$ in the Aiguilles-Rouges; Bussy et al. 2000) in a fast exhuming environment (Capuzzo and Bussy 2000; Genier et al. 2008). Syn- to post-orogenic magma pulses of dominantly granitic composition record different stages of the evolving orogen at ca. 330, 310 and $300 \mathrm{Ma}$ (Schaltegger 1997; Bussy et al. 2000; von Raumer and Bussy 2004).

This general picture stands for the External Crystalline Massifs, which form the basement of the Helvetic realm of the Alps, i.e. the relatively stable part of the European margin of the Alpine Tethys. Things are less clear in more internal zones, as precise ages are scarcer and field relationships are obscured by Alpine tectonics, which dissected the basement into multiple nappes. Conversely, Palaeozoic geology can provide helpful constraints in the reconstruction of the Mesozoic paleogeographic puzzle, as will be attempted in this study.
Variscan magmatic events tend to become younger toward the internal parts of the Alpine belt (Bussy and Cadoppi 1996). The External Massifs do not record intrusions younger than $295 \mathrm{Ma}$ (the Rotondo granite in the Gotthard massif; Sergeev et al. 1995), and the Lower Penninic nappes, which are their southern extension, younger than ca. $290 \mathrm{Ma}$ (Verampio and Antigorio; Bergomi et al. 2007). Further south, the Briançonnais domain contains very few Variscan intrusions older than $270 \mathrm{Ma}$ and only in its distant continuation in Italy: the Costa Citrin granite at $323 \pm 8 \mathrm{Ma}$ (Zone Houillère Briançonnaise; Bertrand et al. 1998) and the Borda granodiorite at 300-294 Ma (Ligurian Briançonnais; Gaggero et al. 2004). All other Variscan intrusions in the Briançonnais basement have ages $\leq 270 \mathrm{Ma}$.

The present study focuses on the dating and characterization of Palaeozoic magmatic rocks from the basements of the Sambuco and Maggia nappes in the Central Lepontine Alps. Both nappes host large and various magmatic bodies, partly dated by Köppel et al. (1981) using large, discordant zircon fractions which yielded suspiciously young ages in the light of recent data on Variscan granites. Here we will date these rocks by an in situ method (the LA-ICPMS technique) that provides $\mathrm{U}-\mathrm{Pb}$ ages of small individual domains in single zircon crystals. We also investigated blocks of gneiss with lamprophyre dykes from a metawildflysch formation in the sedimentary cover (Teggiolo zone) of the underlying Antigorio nappe, in order to constrain their paleogeographic provenance. The results show that the Sambuco nappe records all the main Palaeozoic magmatic episodes known in other basement units of the Alps. In addition, granites from the Maggia nappe are significantly older than formerly proposed by Köppel et al. (1981), which casts some doubts about recent paleogeographic models of the Central Alps (see below).

\section{Geological framework and open controversies}

The Maggia and Sambuco nappes (Fig. 1) are situated in the Lepontine Alps, where insight into the deepest nappes of the Alpine stack is allowed by the Ticino structural culmination. Most of this region is covered by the tectonicpetrographic map (1: 100,000) of the central Lepontine Alps (Berger and Mercolli 2006) and the western sector by the tectonic map $(1: 100,000)$ of the Western Swiss Alps (Steck et al. 1999). In the sectors that concern us directly these synthetic maps are essentially based on the sheets Val Bedretto (Hafner et al. 1975), Basodino (Burckhardt and Günthert 1957) and P. Campo Tencia (Keller et al. 1980) of the 1:25,000 Geological Atlas of Switzerland where many relevant details are figured. 
Fig. 1 Geological map of the northern Maggia area, with sample localities (black stars) and sample names (white boxes). Modified from Berger and Mercolli (2006), Simpson (1981) and Steck et al. (1999). Coordinates of the swiss topographic grid

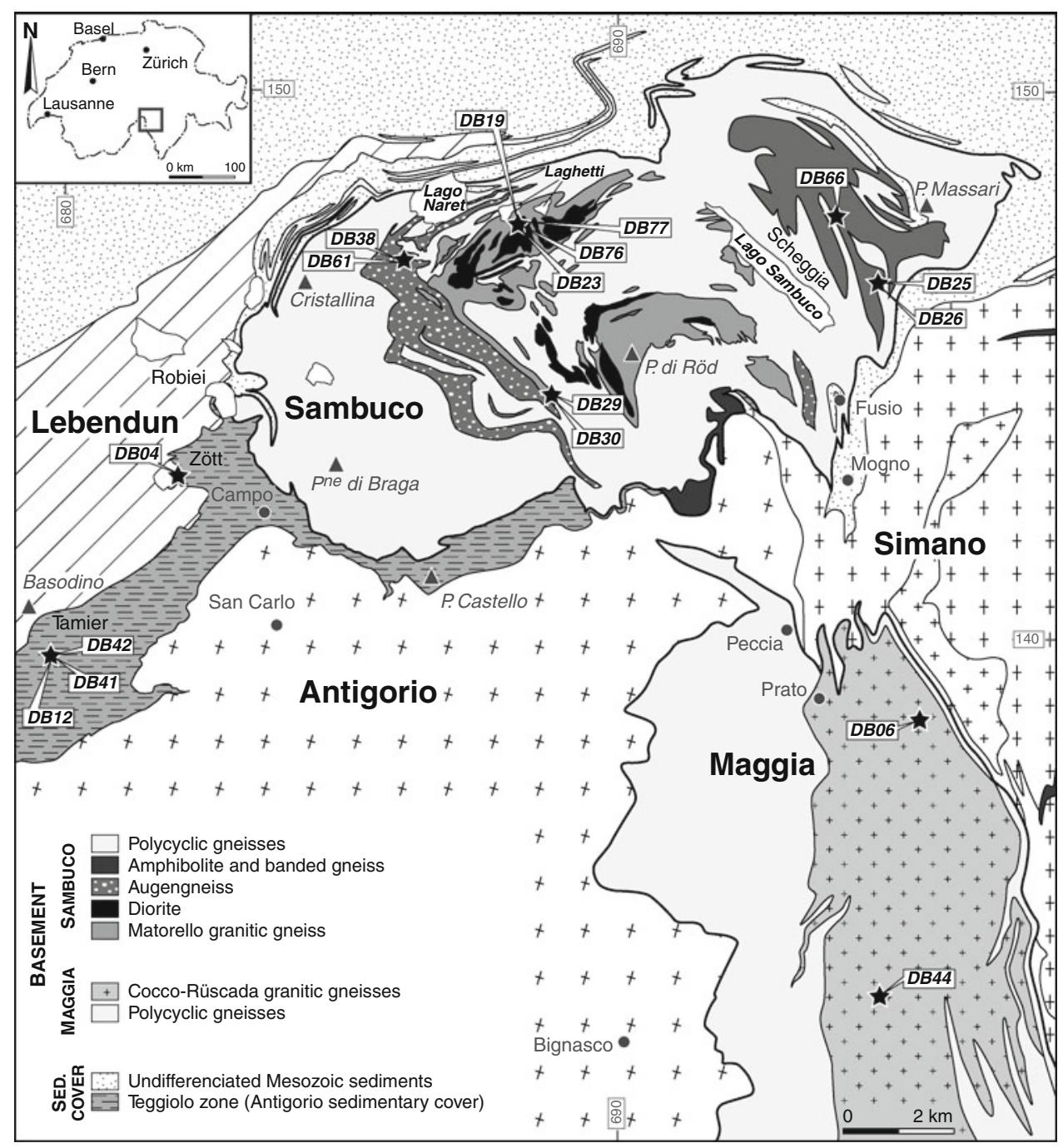

The Lepontine Alps result from the tectonic imbrication and piling up of numerous basement nappes, with or without their Mesozoic cover, originating from different paleogeographic domains. Complex fold interference patterns resulting from intense polyphase deformation, and the potential existence of longitudinal discontinuities in the paleogeography, exclude simple correlations between tectonic structures to the west and to the east of a central zone represented by the Sambuco and Maggia gneissic bodies. Consequently there still is no general agreement on the geometry of the nappe stack in the Central Alps (see contrasted interpretations by Berger et al. 2005; Grujic and Mancktelow 1996; Maxelon and Mancktelow 2005; Steck 1998, 2008).

Berger et al. (2005) introduced into the Lepontine Alps the concept of "tectonic accretion channel" (TAC) (Engi et al. 2001): TAC units are tectonic mélange zones with eclogitic relics interpreted as resulting from intense deformation along plate boundaries during subduction. In the middle part of the Maggia valley the Maggia nappe overlies a band of gneisses associated with metasediments and relics of eclogites and peridotites, called the Someo zone. It has been interpreted by Berger et al. (2005) as a TAC unit. Thus the Someo zone would be a plate boundary, where the relics of mafic and ultramafic rocks would mark the trace of an ocean that disappeared by subduction. This hypothetical oceanic domain would be the so-called Valais ocean, which plays an important role in several recent reconstructions of the Cretaceous paleogeography of the Alps (e.g. Stampfli 1993; Schmid et al. 2004). In these models the Valais ocean is generally coupled with the assumption of a large sinistral transcurrent movement between its margins.

The Maggia and Sambuco gneissic bodies have classically been considered as forming one single tectonic unit called the "Maggia nappe", e.g. on the tectonic map of Switzerland (1: 500,000) (Spicher 1980). However the contact between these two bodies is unclear and poses difficult problems (Keller 1968; Keller et al. 1980; Steck 1998; Berger et al. 2005). Berger et al. (2005) suggested 
that the trace of the Someo zone passes (at least virtually) between Sambuco and Maggia. Consequently they subdivided the classical Maggia (sensu lato) nappe into two distinct tectonic units: (1) the Sambuco nappe, that would belong to the northern ("European") margin of the Valais ocean; and (2) the Maggia (sensu stricto) nappe, that would belong to its southern margin (called "Briançonnais", in a sense of this word that does not coincide with its classical definition based on specific features of the Mesozoic stratigraphy). All these questions are still highly controversial. For instance Steck (2008) accepted the cartographic separation of Sambuco and Maggia s.s., but minimized its significance in considering that they are two parts, linked by complex folds, of the same great tectonic unit.

Here we also accept this separation and consequently we adopt the nomenclature introduced by Berger et al. (2005), using the name Maggia in its new strict sense (Fig. 1). But we let the other controversies open, all the more since Bussy et al. (2005) and Masson et al. (2008) recently demonstrated the Early Carboniferous age of the Versoyen metabasites (on the French-Italian boundary) that were until now supposed to be Cretaceous and considered as the largest remnant of Valais oceanic crust in the Alps. They also proposed an entirely new tectonic framework of this Lower Penninic complex. Recent geochronological data of Beltrando et al. (2007) point to the same direction. These works cast doubt on the very existence of a Valais ocean of Cretaceous age. Other solutions seem possible, and even preferable, to explain the scarce remnants of ophiolitic rocks in the Central Alps, such as localized windows of exhumed subcontinental mantle (which is very different from an oceanic system). Analogies can be drawn with a new category of models of continental break-up based on modern research on the Atlantic margins, which imply extreme extension of wide segments of continental crust with the possible local exhumation of patches or bands of continental mantle (e.g. Jammes et al. 2009; Péron-Pinvidic and Manatschal 2009). In any case we will show in conclusion of this work that if any kind of suture (oceanic or not) passes between Sambuco and Maggia, a transcurrent movement between them is very improbable.

\section{Field relationships}

\subsection{The Sambuco nappe}

The Sambuco nappe consists of a polycyclic crystalline basement partly surrounded by a Triassic to Jurassic sedimentary cover of Helvetic affinity (Délèze 1999; Lodetti 2001). Our observations show that this cover, well represented in the Naret and Cristallina sectors, disappears along the western border of the nappe near Robièi, where the lower limb of the frontal fold passes to a thrust of the Sambuco basement directly over the sedimentary cover of the Antigorio nappe (Fig. 1) (Matasci et al. 2010). Several aspects of its structural evolution have been analyzed in detail by different authors (e.g. Ramsay and Allison 1979; Huber et al. 1980; Simpson 1981, 1982; Mohanty and Ramsay 1994; Grujic and Mancktelow 1996; Steck 1998; Galli et al. 2007). The rocks of the Sambuco nappe are completely recrystallized under amphibolite facies conditions. In its NW part peak Tertiary metamorphic temperature reached $640-650^{\circ} \mathrm{C}$ at a pressure of $8-9 \mathrm{kbar}$ (Galli et al. 2007).

The crystalline basement is similar to that of other "European"-derived basement units, like the Gotthard massif. It includes paragneisses with micaschist and amphibolite horizons, early Palaeozoic orthogneisses, late Palaeozoic granitoids (Matorello pluton) and a large complex of banded, mainly mafic to intermediate magmatic rocks at Alpe Scheggia, NE of Lago Sambuco (Fig. 1).

The Alpe Scheggia complex consists in an association of hornblendite, amphibolite and meso- to leucocratic hornblende and biotite gneisses (Hasler 1949), interpreted as the metamorphic equivalent of a calc-alkaline suite with mafic cumulates, diorite, tonalite, granodiorite and monzogranite (Berger et al. 2005). Mafic microgranular enclaves are common in the intermediate to evolved rocks. Deformation is intense with isoclinal folding and boudinage (Fig. 2).

A large band of coarse-grained porphyric orthogneiss (augengneiss) is outcropping in the western part of the nappe (Fig. 1). It is reminiscent of other orthogneisses intruded during the Ordovician in various Alpine basements. They are well known in the External Crystalline Massifs (see review by Schaltegger and Gebauer 1999), in Briançonnais basements (Guillot et al. 2002 and references therein) as well as in the Austroalpine (Silvretta nappe;

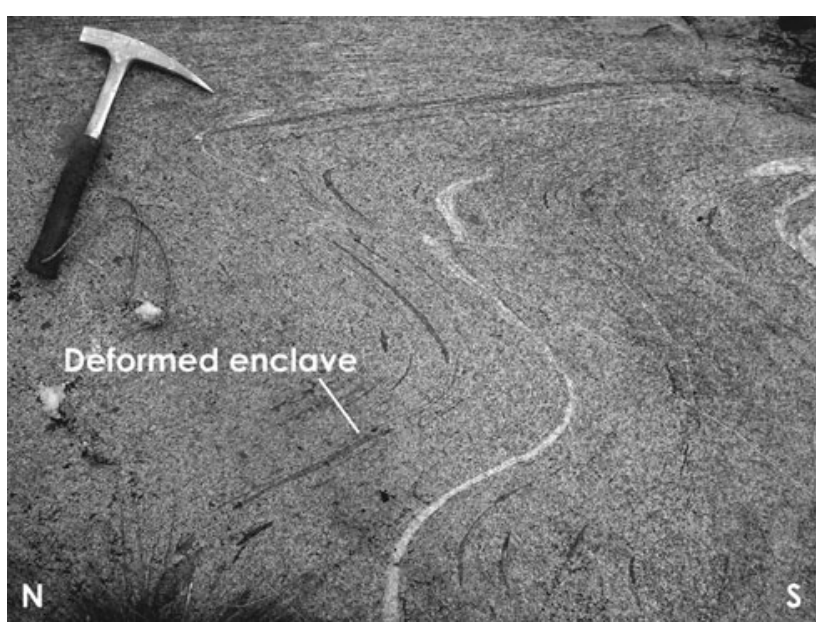

Fig. 2 Diorite (sample DB26) in the Alpe Scheggia complex with deformed mafic enclaves (Alpe Massari; coord. 694,394/146,421) 
Poller et al. 1997). Augengneisses also occur locally in the Alpe Scheggia complex, where they provided whole-rock $\mathrm{Rb} / \mathrm{Sr}$ dates interpreted as indicating a magmatic age in the time span 430-580 Ma (Steiner 1984a).

The late Palaeozoic Matorello pluton occupies a large area in the centre of the Sambuco nappe (Fig. 1). This is a calc-alkaline intrusion with well-preserved magmatic features like sharp contacts with the surrounding rocks, flow layering, enclave swarms, schlieren and composite dykes (Ramsay and Allison 1979; Galli et al. 2007), which document the progressive growth of a sill-like body through multiple magma pulses (Bussien et al. 2008a). The main part of the intrusion is granodioritic. This rock presents a very peculiar texture characterized by small clusters or "nests" of biotite, so singular indeed that Günthert et al. (1976) coined the word "nidoblastic" to name it. Out of the Matorello pluton this texture seems to be known only in the Cocco granite (see below). Quartz-diorite is slightly older, as indicated by mobile internal contacts. Other rock types of minor volumetric importance include lamprophyric, aplitic, pegmatitic and composite dykes. Numerous chemical analyses of all these rocks have been published by Günthert et al. (1976, 1996).

Superimposed folding is the probable cause of the discontinuity of the outcrops which form two large crescent-shape zones (Fig. 1). Inverse gravity indicators in these magmatic rocks demonstrate at several places the overturn of the intrusion by Alpine folding (Bussien et al. 2008a). Strain is strongly partitioned into shear zones, while between them parts of the pluton remain surprisingly well preserved (Ramsay and Allison 1979). Köppel et al. (1981) published zircon U-Pb analyses that suggest that the formation of the Matorello granite occurred about $300 \mathrm{Ma}$ ago. Bussien et al. (2008b) dated by LA-ICPMS zircons from a lamprophyric dyke intruded into the Matorello granodiorite at Laghetti and found an age of $290.5 \pm 3.7 \mathrm{Ma}$.

\subsection{The Maggia nappe}

According to Berger et al. (2005), the Maggia nappe s.s. is a pure basement nappe without sedimentary cover. It consists of a polycyclic gneiss complex to the west and of the late Palaeozoic Cocco-Rüscada granitic intrusions to the east (Fig. 1). The polycyclic complex is dominated by plagioclase-quartz-biotite gneisses with subordinate metasediments, amphibolites and migmatites. It has been intruded by two granitic masses, the Cocco and Rüscada calc-alkaline plutons (Preiswerk 1931; Grütter and Preiswerk 1936; Buchmann 1953).

The Cocco mesocratic orthogneiss is strikingly similar to the Matorello granodiorite, with the same composition, flaser structure and biotite nests; it also hosts mafic enclave swarms and synplutonic dykes. This similarity was already noted by Preiswerk (1925, p. 184), who emphasized their difference with all the other granites of the Central Alps. It was also underlined by Buchmann (1953), who concluded that these two granites are cogenetic and suggested that they initially formed a single magmatic body and have been separated by Alpine tectonics.

The Rüscada leucogranites form the northern termination of the Cocco-Rüscada intrusions (Preiswerk 1931; Buchmann 1953; Keller et al. 1980). They are differentiated rocks which intruded both the Cocco gneiss and the polycyclic gneisses.

Köppel et al. (1981) obtained a U-Pb age of 270-285 Ma on monazite from Cocco, interpreted as the time of granite crystallization, and discordant zircon ages around 240-260 Ma for the Rüscada orthogneiss, all significantly younger than the $300 \mathrm{Ma}$ old Matorello granite.

\subsection{Blocks in the Robièi Formation (Teggiolo zone, Antigorio nappe)}

The Antigorio nappe is a large tectonic unit situated below the Sambuco and Maggia nappes. It is made of an orthogneissic basement surmounted on its NW border by a sedimentary cover called the Teggiolo zone (Fig. 1). This zone can be subdivided into several lithostratigraphic formations, the highest of which is a several hm thick band of calcschist characterized by the presence of blocks of various nature and size (from a few $\mathrm{dm}$ to several $\mathrm{hm}$ ). This lithostratigraphic subdivision has been named the Robièi Formation and is interpreted as a meta-wildflysch of probable Tertiary age (Masson 2002; Bussien et al. 2008b; Matasci et al. 2010). Blocks of gneiss are often abundant in the top part of this formation. A remarkable feature of these blocks is the frequent presence of lamprophyric dykes. These are particularly conspicuous at the Tamier and Zött localities, where Bussien et al. (2008b) studied their mineralogy and geochemistry. These authors also dated zircons with a SHRIMP ion microprobe $(284.8 \pm 1.7 \mathrm{Ma}$ at Tamier and $290.0 \pm 1.3 \mathrm{Ma}$ at Zött) and concluded to their chemical and age similarity with the lamprophyres of the Sambuco nappe. We sampled gneisses and lamprophyres from these blocks for comparison with the Sambuco and Maggia rocks.

\section{Investigated rocks and their geochemical composition}

\subsection{Introduction}

The main rock types of the Sambuco and Maggia nappes have been sampled for zircon dating and geochemistry. This includes the banded mafic complex of Alpe Scheggia, 


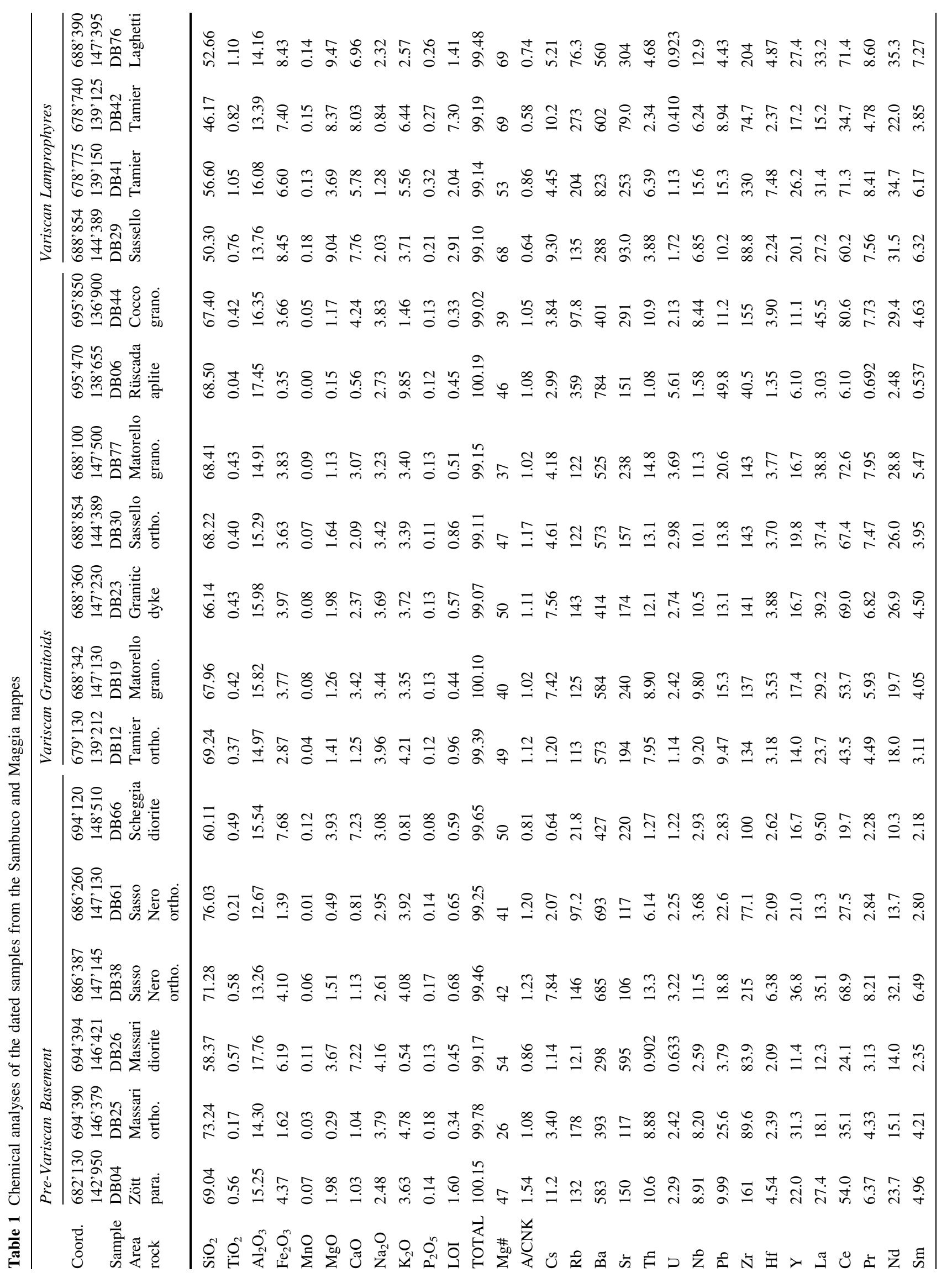




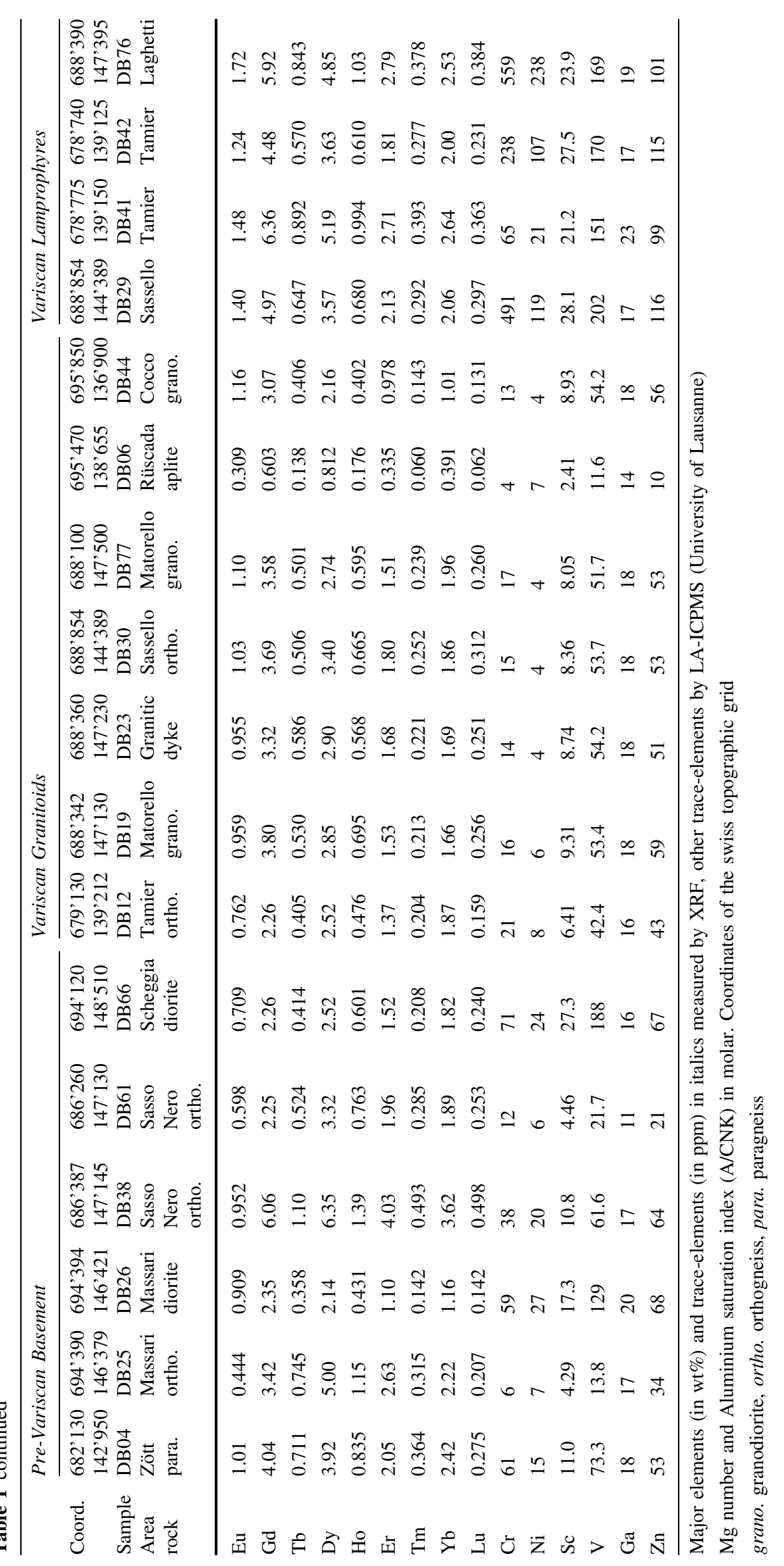


the early Paleozoic orthogneisses, a paragneiss, late Paleozoic granitoids (Matorello, Cocco, Rüscada) and lamprophyres. Coordinates of sampling localities and whole-rock chemical analyses are reported in Table 1.

Alpine metamorphism and deformation not only modified the mineralogy and texture of the rocks, but may also have affected the whole-rock chemical composition, like the $\mathrm{K}, \mathrm{Na}$ and $\mathrm{Ca}$ contents. This might slightly influence the position of the analytical points in the R1R2 classification diagram of de La Roche et al. (1980). Even if detailed chemical investigations of Sambuco rocks show that in general metamorphic recrystallization and deformation were essentially isochemical (Kerrich et al. 1977, and Simpson 1981, although contradicted by Mohanty and Ramsay 1994; Steiner 1984b), there are also cases where whole-rock metasomatic effects are observed or suspected (e.g. in the Zött lamprophyres; Bussien et al. 2008b).

\subsection{The banded mafic complex of Alpe Scheggia}

Sample DB26 has been taken at Alpe Massari, E of Lago Sambuco, a few tens of meters north of the old chalets (Fig. 1; cf. map of Hasler (1949)). It is a fine-grained mesocratic diorite hosting stretched dark microgranular enclaves (Fig. 2). The mineral assemblage is plagioclase, green amphibole, biotite, quartz and accessories (apatite, rutile, sphene, zircon and ores), preferentially oriented in a planar gneissic texture. Final recrystallization postdates deformation as plagioclase crystals are polygonal and show equilibrium triple-point texture. Sample DB66 has been collected at Alpe Scheggia. It differs from DB26 by the presence of epidote. More mafic rocks have been avoided because of their potential lack of zircons and more granitic ones because they are susceptible to be later injections unrelated to the mafic magmatism.

Samples DB26 and DB66 have similar chemical compositions with 58 and $60 \mathrm{wt} \% \mathrm{SiO}_{2}$, respectively (Table 1) and fall in the diorite field of the R1R2 classification diagram (Fig. 3; de La Roche et al. 1980). They are typically low-K calc-alkaline rocks $\left(0.54\right.$ and $0.81 \mathrm{wt} \% \mathrm{~K}_{2} \mathrm{O} ; 0.57$ and $0.49 \mathrm{wt} \% \mathrm{TiO}_{2} ;<3 \mathrm{ppm} \mathrm{Nb}$ ) and display a rather low $\mathrm{Mg \#} \mathrm{(54} \mathrm{and} \mathrm{50,} \mathrm{considering} \mathrm{the} \mathrm{total} \mathrm{amount} \mathrm{of} \mathrm{Fe).} \mathrm{Their}$ REE patterns (Fig. 4) are regularly fractionated [(La/ $\mathrm{Lu})_{\mathrm{N}}=8.9$ and 4.1 , respectively] without significant Eu anomaly (1.17 and 0.97).

\subsection{Pre-Variscan orthogneisses}

Two types of orthogneisses have been sampled: a finegrained one in the Alpe Scheggia complex at Alpe Massari (DB25), and a coarse-grained gneiss at the Sasso Nero Pass, SSW of the Lago del Naret (DB38 and DB61; Fig. 1).
Sample DB25 was collected in a deformed, m-wide band of augengneiss with cm-long K-feldspar phenocrysts in a light grey matrix of mm-granulometry, about $10 \mathrm{~m} \mathrm{~W}$ of the Massari chalet. This augengneiss is part of the Scheggia mafic complex, but contacts are not visible on the sampling site. The mineral assemblage is quartz, plagioclase, K-feldspar, biotite, white mica and accessories (epidote, zircon, apatite, sphene, ores). Preferred orientation of the two micas underlines a planar gneissic structure. Matrix texture is granoblastic. The K-feldspar phenocrysts are marginally granulated due to deformation and display perthites, but no significant alteration. Biotite is slightly dominant over the white mica and both have the same grain size, which suggests that the white mica is a primary magmatic phase. This is supported by the dominant S7 morphology of the zircons (Pupin 1980), typical of peraluminous two-mica S-type granites.

Sample DB25 is a syenogranite according to the R1R2 classification (Fig. 3; de La Roche et al. 1980), of ferroan alkali-calcic peraluminous type (Frost et al. 2001). It has an evolved chemical composition with $73.2 \mathrm{wt} \% \mathrm{SiO}_{2}$, a $\mathrm{Mg \#}$ of 26 , low $\mathrm{TiO}_{2}, \mathrm{CaO}$ and $\mathrm{MgO}$ contents of $0.17,1.04$ and $0.29 \mathrm{wt} \%$, respectively. The aluminium saturation index is relatively low $(\mathrm{A} / \mathrm{CNK} \mathrm{mol}=1.07)$, but it might have been affected by metamorphic remobilization. Trace element contents are in keeping with the evolved nature of the rock, with low values for transition elements $(\mathrm{Cr}, \mathrm{Ni}, \mathrm{Sc}$, $\mathrm{V})$ and $\mathrm{Zr}(90 \mathrm{ppm}) . \mathrm{REE}$ are regularly fractionated [(La/ $\left.\mathrm{Lu})_{\mathrm{N}}=9.0\right]$ with an expected strong negative Eu anomaly $\left(\mathrm{Eu} / \mathrm{Eu}^{*}=0.35\right.$; Fig. 4).

DB38 and DB61 are two samples of the same orthogneiss unit at the Sasso Nero Pass, taken a few tens of meters away from each other. The main facies (DB38) is an augengneiss with a high proportion of K-feldspar phenocrysts up to $4-5 \mathrm{~cm}$ long in a relatively coarse-grained matrix. This metagranite is heterogeneous with some microgranular enclaves, biotite schlieren and aplitic dykes. Sample DB61 is an evolved leucocratic facies, homogeneous and medium-grained. Both samples have the same mineralogy as DB25, but biotite crystals are usually bigger than those of white mica. Both micas underline the schistosity (S) component of a $\mathrm{C}-\mathrm{S}$ structure in the rock.

Both samples are calc-alkaline syenogranites (Fig. 3; de La Roche et al. 1980; Frost et al. 2001) with the same Mg\# of 40. Zircon morphology is dominantly of type S7 (Pupin 1980), in agreement with the peraluminous character of the rock. Difference in chemical composition between DB61 and DB38 is mainly due to their contrasted biotite content. Leucogranite DB61 is thus higher in $\mathrm{SiO}_{2}$ (76 wt\%), whereas DB38 is higher in biotite components like Fe, $\mathrm{Mg}$, $\mathrm{Ti}, \mathrm{Rb}, \mathrm{Cr}, \mathrm{V} . \mathrm{Zr}$ is also elevated in this sample (215 ppm), which is ascribed to numerous zircon inclusions in the biotite. The REE content of DB38 is significantly higher 
Fig. 3 Position of studied rocks in the R1-R2 diagram of de La Roche et al. (1980)

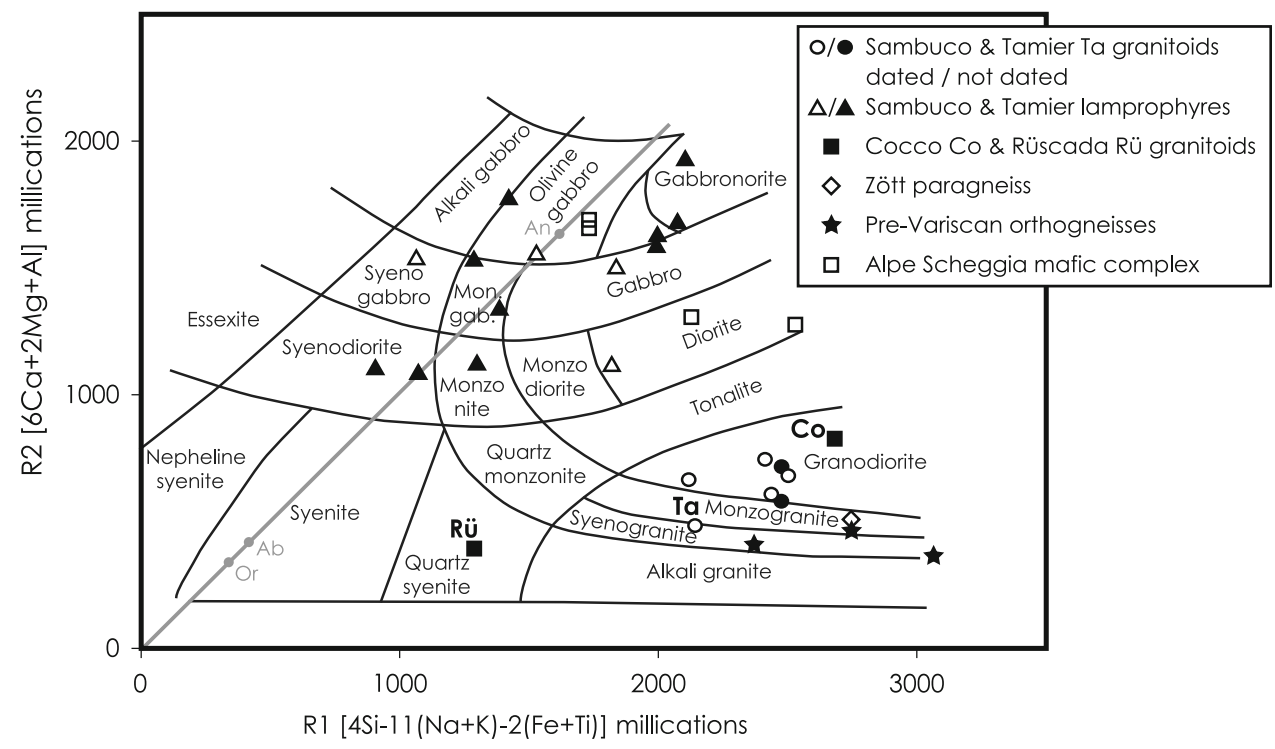

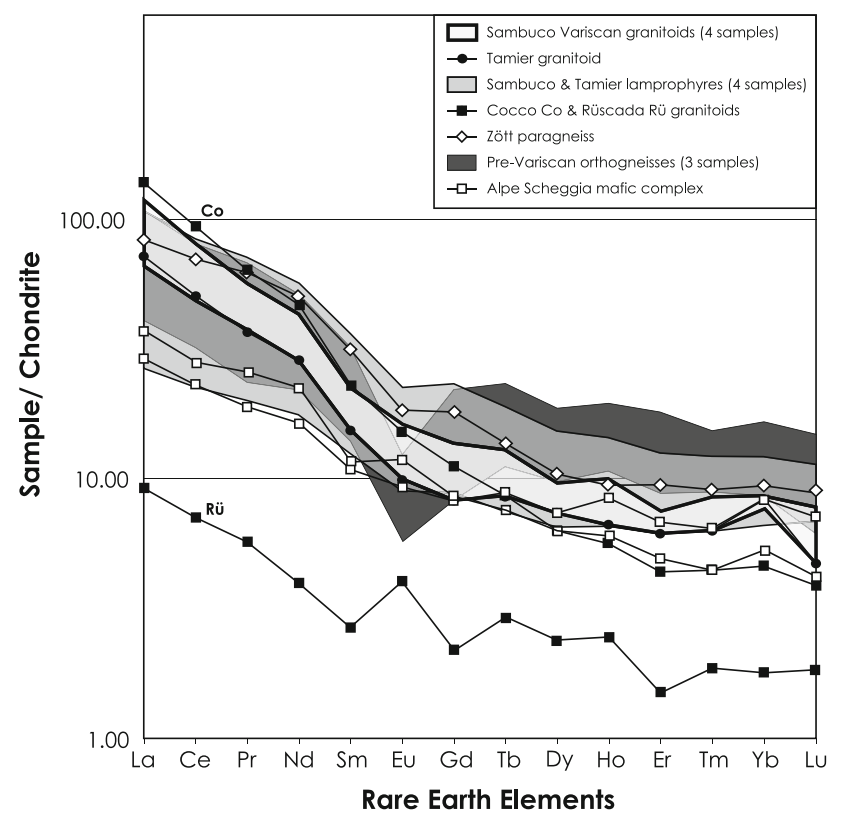

Fig. 4 Normalization diagram of the REE composition of the dated samples. Chondritic reference values from Nakamura (1974) and Boynton (1984)

than that of DB61 (35 and $13 \mathrm{ppm} \mathrm{La,} \mathrm{respectively),} \mathrm{but}$ both display comparable chondrite normalized patterns with a stronger fractionation of LREE $\left[(\mathrm{La} / \mathrm{Sm})_{\mathrm{N}}=3.34\right.$; DB38] than of HREE $\left[(\mathrm{Gd} / \mathrm{Lu})_{\mathrm{N}}=1.50\right]$ and a significant negative Eu anomaly $\left(\mathrm{Eu} / \mathrm{Eu}^{*}=0.46\right.$; Fig. 4$)$.

\subsection{Zött paragneiss block}

A paragneiss sample (DB04) has been taken near Lago del Zött (Fig. 1) in a $10 \mathrm{~m}$-long gneiss block embedded in a calcschist that belongs to the Robiè Formation of the
Teggiolo zone (see above). The sampled block contains a lamprophyric dyke.

Sample DB04 is a dark grey paragneiss rich in biotite and white mica. Other minerals are quartz, plagioclase, garnet and accessories (epidote, sphene, apatite, zircon). Zircons are often rounded, in keeping with the sedimentary origin of the rock. This rock has a rather evolved composition with $69 \mathrm{wt} \% \mathrm{SiO}_{2}$; its overall major-, trace- and rareearth element composition is similar to that of NASC (North Atlantic Shale Composite; Gromet et al. 1984).

\subsection{Late Palaeozoic granitoids and lamprophyres}

\subsubsection{Maggia granitoids}

The relatively young age (270-285 Ma) proposed by Köppel et al. (1981) and adopted on the map of Berger and Mercolli (2006) for the Cocco granite seems to contradict the hypothesis, based on their great petrographical similarity (see above), of its cogenetism with the $300 \mathrm{Ma}$ old Matorello intrusion. This is why we resampled the Cocco and Rüscada granites in the Maggia nappe at the locations mentioned by Köppel et al. (1981).

Sample DB44 has been collected on a glacial polished outcrop in the Tomè valley. It is a coarse-grained (up to $1 \mathrm{~cm}$ ) orthogneiss with the typical biotite nests, hosting mafic enclaves with lobate outlines attesting magma mingling processes. Synplutonic mafic dykes and aplites are also present. Alpine deformation is weak and the magmatic texture is preserved. The mineralogical assemblage is quartz, plagioclase $\left(\mathrm{An}_{28-39}\right)$, K-feldspar, biotite $\left(\mathrm{Mg} / \mathrm{Fe}^{*}\right.$ cat $=0.58-0.74)$, secondary epidote and chlorite, apatite, zircon, sphene and allanite. The chemical composition reveals a magnesian calcic peraluminous granodiorite 
(Fig. 3; Frost et al. 2001; de La Roche et al. 1980), comparable to the Matorello except for its lower $\mathrm{K}_{2} \mathrm{O}$ content of $1.46 \mathrm{wt} \%$ (ca. $3.40 \%$ for the Matorello granodiorite). REE are regularly fractionated $\left[(\mathrm{La} / \mathrm{Lu})_{\mathrm{N}}=35.8\right.$; Fig. 4].

Sample DB06 is an aplitic facies of the Rüscada leucogranite, collected in an alternation of biotite gneiss and aplitic bands in the bed of a torrent near the village of Faèd. This rock is composed of quartz and K-feldspar with a granoblastic texture, with minor albite, secondary sericite, apatite and zircon. The whole-rock chemical composition reflects the high abundance of K-feldspar with high contents in $\mathrm{K}_{2} \mathrm{O}, \mathrm{Ba}$ and $\mathrm{Rb}(9.85 \mathrm{wt} \%, 784$ and $359 \mathrm{ppm}$, respectively) and a REE normalized pattern typical of that mineral with low concentrations $(\mathrm{La}=3 \mathrm{ppm})$ and a positive Eu anomaly (Eu/Eu* = 1.66; Fig. 4).

\subsubsection{Sambuco granitoids}

The Late Paleozoic magmatic activity in the Sambuco nappe is represented by the Matorello intrusion. Samples DB19 and DB77 were collected in the main granodiorite south of the Laghetti lakes (Fig. 1). It is a rather coarsegrained, light grey rock with crystals up to $1 \mathrm{~cm}$ in diameter and the typical biotite nests. Deformation is weak or absent. The mineral assemblage is quartz, plagioclase (ca. $\mathrm{An}_{35}$ ), K-feldspar, biotite, accessories (apatite, zircon, allanite, sphene) with secondary epidote and white mica. The chemical composition of both samples is almost identical (Table 1) and corresponds to a magnesian alkalicalcic, slightly peraluminous granodiorite (Fig. 3; Frost et al. 2001; de La Roche et al. 1980) with $68 \mathrm{wt} \% \mathrm{SiO}_{2}$, $\mathrm{Mg} \#=40$ and $\mathrm{A} / \mathrm{CNK}=1.02$. LREE are more fractionated $\left[(\mathrm{La} / \mathrm{Sm})_{\mathrm{N}}=4.5\right]$ than HREE $\left[(\mathrm{Gd} / \mathrm{Lu})_{\mathrm{N}}=1.82\right]$ and the $\mathrm{Eu}$ anomaly is moderate $\left(\mathrm{Eu} / \mathrm{Eu}^{*}=0.74\right)$ (Fig. 4). Zircon morphology is dominantly of S12 type, but S14, $\mathrm{S} 17$ and S18 are also present, as expected in calc-alkaline granites (Pupin 1980).

A third granodiorite sample (DB23) was collected from a 2 meter-wide dyke crosscutting the quartz-diorite in the Laghetti area (Fig. 1). Contacts are sharp and sinuous, indicating that the diorite was not totally crystallized at time of dyke injection. The rock is porphyric with up to $1 \mathrm{~cm}$-long $\mathrm{K}$-feldspar phenocrysts in a leucocratic fine-grained matrix. Mineralogy, zircon morphology and whole-rock chemical composition are similar to the main granodiorite. The normalized REE pattern overlaps that of samples DB19 and DB77.

Sample DB30 is a highly deformed orthogneiss hosting an equally deformed lamprophyre dyke (DB29), in the middle part of Val Peccia beside the Sassello chapel. This rock was supposed to be an equivalent of the Sasso Nero older augengneiss (Simpson 1983). However, its mineralogy, chemistry and zircon morphology are similar to the
Matorello granodiorite. We consider it as a deformed equivalent of the latter.

\subsubsection{Orthogneiss blocks}

The gneiss blocks embedded in the Robièi Formation of the Teggiolo zone (see above) are not all of sedimentary origin. Many are orthogneisses and some of them host lamprophyre dykes. Sample DB12 was collected at the Tamier Pass, $\mathrm{S}$ of the Basodino peak (Fig. 1), in a large orthogneiss block intruded by a lamprophyre dyke. The block is intensely folded and displays a penetrative schistosity. The magmatic origin of the gneiss is revealed by small eyes of $\mathrm{K}$-feldspar (mm size), inducing a isometric texture. This rock is similar to the Matorello granodiorite with a higher proportion of white mica, probably of secondary origin, which might be responsible for the higher $\mathrm{A} / \mathrm{CNK}$ ratio of 1.12. The chemical composition is also comparable, with a slightly higher Mg\# of 49 (37-40 for the Matorello; Table 1) and lower REE contents (e.g. $23.7 \mathrm{ppm}$ La against $38.8 \mathrm{ppm}$ for DB77). Zircon morphology is the same.

\subsubsection{Lamprophyres}

Ramsay and Allison (1979) distinguished two generations of lamprophyric dykes (early $\lambda 1$ and late $\lambda 2$ ) in the Laghetti area. They are dark grey, black or greenish, massive and homogeneous. Texture is usually granoblastic and poorly oriented. Contacts with the host Matorello granodiorite are sharp, sometimes sinuous. A cm-wide biotite-rich reaction rim is locally developed in the host, ascribed to the release of fluids during crystallization of the lamprophyre. Dyke width is variable from a few $\mathrm{cm}$ to one meter and their length varies between ten and hundreds of meters. They are variably affected by folding and shearing, however, schistosity is usually weak or absent. One sample of each generation has been collected, DB75 in $\lambda 1$ and DB76 in $\lambda 2$. Bussien et al. (2008b) obtained a LA-ICPMS U-Pb zircon age of $290.5 \pm 3.7$ Ma on DB75. Both lamprophyre types have the same mineralogical assemblage consisting of biotite, Mg-hornblende (with rare actinolite overgrowth), plagioclase $\left(\mathrm{An}_{35-15}\right)$, K-feldspar, quartz, epidote and chlorite. Accessories include apatite, zircon and sphene.

DB29 comes from a $20 \mathrm{~cm}$ thick, highly deformed lamprophyric dyke intruded into the Sassello chapel orthogneiss (DB30, see above). Its mineralogy is similar to that of the Laghetti samples, with additional calcite, thought to be post-magmatic.

Two lamprophyres have also been sampled in orthogneiss blocks (comparable to sample DB12) embedded in the calcschists of the Robiei Formation (Teggiolo zone) at the Tamier Pass (DB41 and DB42) (Fig. 1). These are 

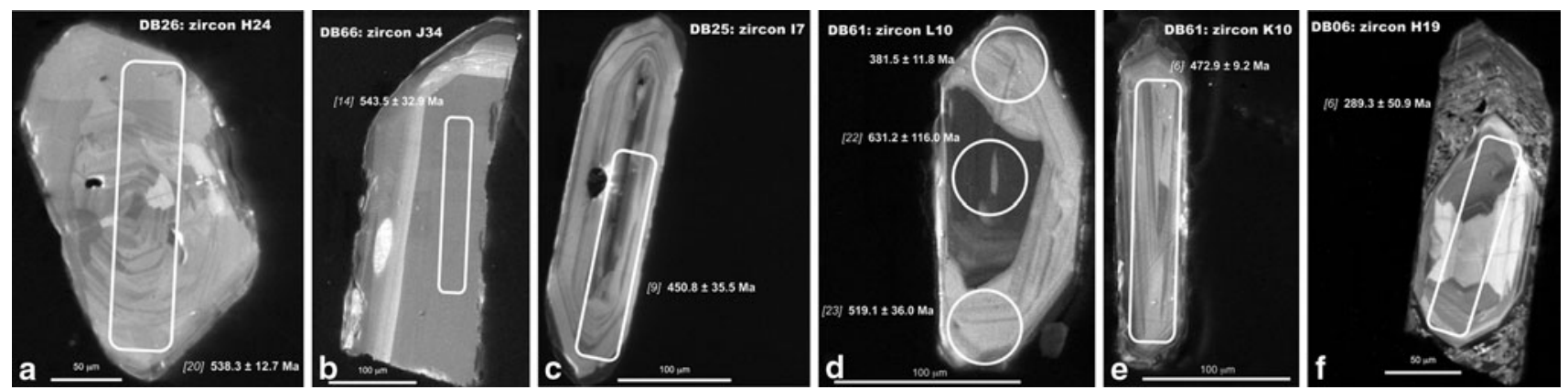

Fig. 5 Cathodoluminescence images of zircons from samples DB06, DB25, DB26, DB61 (2 grains) and DB66 with location of U-Pb

${ }^{206} \mathrm{~Pb} /{ }^{238} \mathrm{U}$ ages are reported with error at the 2-sigma level. analytical spots (d) or profile $(\mathbf{a}-\mathbf{c}, \mathbf{e}, \mathbf{f})$. The corresponding

Bracketed numbers correspond to spot numbers in Tables 2 and 3. See text for discussion

Table $2 \mathrm{U}-\mathrm{Pb}$ isotope data on zircons from pre-Variscan basement rocks (LA-ICPMS, Univ. Lausanne)

\begin{tabular}{lllllllll}
\hline Spot Analyse number & ${ }^{207} \mathrm{~Pb} /{ }^{235} \mathrm{U}$ & $\pm 1 \sigma$ & ${ }^{206} \mathrm{~Pb} /{ }^{238} \mathrm{U}$ & $\pm 1 \sigma$ & Rho & $\begin{array}{l}{ }^{207} \mathrm{~Pb} /{ }^{235} \mathrm{U} \text { apparent } \\
\text { age (Ma) }\end{array}$ & $\begin{array}{c} \pm 2 \sigma \\
{ }^{206} \mathrm{~Pb} /{ }^{238} \mathrm{U} \text { apparent } \\
\text { age (Ma) }\end{array}$ & \begin{tabular}{c} 
$\pm 2 \sigma$ \\
\hline
\end{tabular}
\end{tabular}

Pre-Variscan Basement

DB25 Massari augengneiss

\begin{tabular}{|c|c|c|c|c|c|c|c|c|c|c|}
\hline 1 & $\mathrm{G} 2$ & 0.5889 & 410 & 0.0745 & 42 & 0.4008 & 470.1 & 52.4 & 463.1 & 49.9 \\
\hline 2 & G3 & 0.5983 & 290 & 0.0732 & 27 & 0.3785 & 476.2 & 36.8 & 455.6 & 32.2 \\
\hline 3 & $\mathrm{H} 2$ & 0.5949 & 369 & 0.0766 & 40 & 0.4183 & 474.0 & 47.0 & 475.8 & 47.6 \\
\hline 4 & $\mathrm{H} 3$ & 0.5849 & 272 & 0.0741 & 26 & 0.3766 & 467.6 & 34.8 & 461.0 & 31.2 \\
\hline 5 & H5 & 0.5996 & 434 & 0.0768 & 44 & 0.3920 & 477.0 & 55.1 & 476.9 & 52.2 \\
\hline 6 & I1 & 0.5859 & 242 & 0.0734 & 21 & 0.3504 & 468.3 & 30.9 & 456.7 & 25.5 \\
\hline 7 & I4 & 0.5889 & 552 & 0.0755 & 59 & 0.4176 & 470.2 & 70.6 & 468.9 & 70.8 \\
\hline 8 & I6 & 0.5754 & 242 & 0.0737 & 21 & 0.3440 & 461.5 & 31.2 & 458.7 & 25.6 \\
\hline 9 & I7 & 0.5653 & 398 & 0.0724 & 30 & 0.2899 & 455.0 & 51.6 & 450.8 & 35.5 \\
\hline 10 & I8 & 0.5922 & 89 & 0.0754 & 9 & 0.4149 & 472.3 & 11.3 & 468.4 & 11.2 \\
\hline DB38 & \multicolumn{10}{|c|}{ Sasso Nero augengneiss } \\
\hline 1 & $\mathrm{H} 2$ & 0.8528 & 374 & 0.0982 & 34 & 0.3934 & 626.2 & 41.0 & 603.8 & 39.8 \\
\hline 2 & $\mathrm{H} 3$ & 0.8745 & 1007 & 0.0988 & 92 & 0.4040 & 638.0 & 109.1 & 607.3 & 107.8 \\
\hline 3 & $\mathrm{H} 13$ & 0.8437 & 1,188 & 0.0974 & 115 & 0.4189 & 621.2 & 130.9 & 599.3 & 135.0 \\
\hline 4 & H15 & 0.8253 & 139 & 0.0987 & 13 & 0.3772 & 611.0 & 15.5 & 606.9 & 14.7 \\
\hline 5 & $\mathrm{I} 10$ & 0.8845 & 528 & 0.0964 & 38 & 0.3324 & 643.4 & 56.9 & 593.1 & 45.0 \\
\hline 6 & $\mathrm{I} 22$ & 0.8392 & 300 & 0.0963 & 32 & 0.4652 & 618.7 & 33.1 & 593.0 & 37.6 \\
\hline DB61 & \multicolumn{10}{|c|}{ Sasso Nero augengneiss } \\
\hline 1 & $\mathrm{~J} 1$ & 0.8612 & 165 & 0.1008 & 11 & 0.2939 & 630.8 & 18.0 & 619.3 & 13.3 \\
\hline 2 & $\mathrm{~J} 1-2$ & 0.6054 & 213 & 0.0770 & 21 & 0.3866 & 480.6 & 27.0 & 478.3 & 25.1 \\
\hline 3 & $\mathrm{~J} 2-2$ & 0.7375 & 384 & 0.0875 & 36 & 0.4002 & 560.9 & 44.9 & 540.6 & 43.2 \\
\hline 4 & K3 & 0.5326 & 1,111 & 0.0669 & 67 & 0.2387 & 433.5 & 147.2 & 417.4 & 80.5 \\
\hline 5 & K4 & 0.6318 & 531 & 0.0737 & 41 & 0.3342 & 497.2 & 66.0 & 458.5 & 49.7 \\
\hline 6 & K10 & 0.5891 & 90 & 0.0761 & 8 & 0.3291 & 470.3 & 11.5 & 472.9 & 9.2 \\
\hline 7 & $\mathrm{~K} 11-2$ & 0.7175 & 949 & 0.0846 & 109 & 0.4861 & 549.2 & 112.2 & 523.4 & 129.2 \\
\hline 8 & K12 & 0.5934 & 486 & 0.0764 & 30 & 0.2398 & 473.0 & 61.9 & 474.4 & 35.9 \\
\hline 9 & K13-2 & 0.5183 & 406 & 0.0661 & 45 & 0.4382 & 424.0 & 54.3 & 412.8 & 54.9 \\
\hline 10 & K16 & 0.5212 & 496 & 0.0677 & 52 & 0.4018 & 426.0 & 66.3 & 422.1 & 62.5 \\
\hline 11 & K17 & 0.8719 & 978 & 0.1028 & 92 & 0.4006 & 636.6 & 106.1 & 630.6 & 108.0 \\
\hline 12 & $\mathrm{~K} 17-2$ & 0.7318 & 442 & 0.0895 & 44 & 0.4094 & 557.6 & 51.8 & 552.8 & 52.3 \\
\hline 13 & K19 & 0.7109 & 1,707 & 0.0853 & 200 & 0.4893 & 545.3 & 202.6 & 527.9 & 238.2 \\
\hline
\end{tabular}


Table 2 continued

\begin{tabular}{|c|c|c|c|c|c|c|c|c|c|c|}
\hline Spot & Analyse number & ${ }^{207} \mathrm{~Pb} /{ }^{235} \mathrm{U}$ & $\pm 1 \sigma$ & ${ }^{206} \mathrm{~Pb} /{ }^{238} \mathrm{U}$ & $\pm 1 \sigma$ & Rho & $\begin{array}{l}{ }^{207} \mathrm{~Pb} /{ }^{235} \mathrm{U} \text { apparent } \\
\text { age }(\mathrm{Ma})\end{array}$ & $\pm 2 \sigma$ & $\begin{array}{l}{ }^{206} \mathrm{~Pb} /{ }^{238} \mathrm{U} \text { apparent } \\
\text { age }(\mathrm{Ma})\end{array}$ & $\overline{ \pm 2 \sigma}$ \\
\hline 14 & K19-2 & 0.5067 & 539 & 0.0643 & 61 & 0.4436 & 416.2 & 72.6 & 402.0 & 73.5 \\
\hline 15 & $\mathrm{~K} 23$ & 0.5306 & 339 & 0.0695 & 34 & 0.3827 & 432.2 & 45.0 & 433.0 & 41.0 \\
\hline 16 & K54 & 0.8536 & 788 & 0.1026 & 70 & 0.3688 & 626.6 & 86.3 & 629.4 & 81.6 \\
\hline 17 & L1-2 & 0.8871 & 668 & 0.1063 & 56 & 0.3522 & 644.8 & 71.9 & 651.1 & 65.7 \\
\hline 18 & L3 & 0.6695 & 1,318 & 0.0868 & 63 & 0.1837 & 520.4 & 160.3 & 536.5 & 74.4 \\
\hline 19 & L4 & 0.8733 & 242 & 0.1047 & 15 & 0.2525 & 637.4 & 26.2 & 642.1 & 17.1 \\
\hline 20 & L5 & 0.6079 & 417 & 0.0763 & 25 & 0.2363 & 482.2 & 52.7 & 473.8 & 29.6 \\
\hline 21 & L8 & 0.5982 & 360 & 0.0772 & 26 & 0.2822 & 476.1 & 45.7 & 479.4 & 31.4 \\
\hline 22 & L10 & 0.8503 & 1,060 & 0.1029 & 99 & 0.3869 & 624.8 & 116.3 & 631.2 & 116.0 \\
\hline 23 & L10-2 & 0.6766 & 541 & 0.0839 & 30 & 0.2255 & 524.7 & 65.6 & 519.1 & 36.0 \\
\hline 24 & L14 & 0.6064 & 461 & 0.0748 & 52 & 0.4579 & 481.3 & 58.3 & 464.8 & 62.4 \\
\hline 25 & L19 & 0.5102 & 339 & 0.0666 & 31 & 0.3510 & 418.6 & 45.6 & 415.9 & 37.6 \\
\hline 26 & $\mathrm{~L} 23$ & 0.5149 & 350 & 0.0663 & 35 & 0.3916 & 421.7 & 46.9 & 414.1 & 42.7 \\
\hline 27 & $\mathrm{~L} 27$ & 0.8883 & 980 & 0.1055 & 97 & 0.4191 & 645.5 & 105.3 & 646.4 & 113.7 \\
\hline 28 & L40-2 & 0.5398 & 308 & 0.0693 & 25 & 0.3123 & 438.3 & 40.7 & 432.0 & 29.8 \\
\hline 29 & L40-3 & 0.5178 & 261 & 0.0647 & 18 & 0.2678 & 423.7 & 35.0 & 404.2 & 21.2 \\
\hline DB26 & Massari diorite & & & & & & & & & \\
\hline 1 & G1 & 0.7109 & 1,565 & 0.0883 & 67 & 0.1718 & 545.3 & 185.7 & 545.5 & 79.1 \\
\hline 2 & G3-2 & 0.7048 & 830 & 0.0857 & 90 & 0.4432 & 541.6 & 98.9 & 530.2 & 106.3 \\
\hline 3 & G4 & 0.7197 & 145 & 0.0903 & 9 & 0.2562 & 550.5 & 17.1 & 557.3 & 11.0 \\
\hline 4 & G4-2 & 0.6779 & 671 & 0.0823 & 63 & 0.3842 & 525.5 & 81.2 & 509.6 & 74.5 \\
\hline 5 & G5 & 0.7396 & 843 & 0.0891 & 81 & 0.3995 & 562.2 & 98.5 & 550.0 & 96.1 \\
\hline 6 & G5-2 & 0.6714 & 201 & 0.0847 & 17 & 0.3396 & 521.6 & 24.4 & 524.1 & 20.4 \\
\hline 7 & G6 & 0.7513 & 715 & 0.0898 & 69 & 0.4024 & 569.0 & 82.9 & 554.1 & 81.4 \\
\hline 8 & G7 & 0.7302 & 718 & 0.0884 & 67 & 0.3830 & 556.7 & 84.2 & 546.2 & 78.9 \\
\hline 9 & G8 & 0.7024 & 421 & 0.0861 & 32 & 0.3053 & 540.2 & 50.2 & 532.4 & 37.4 \\
\hline 10 & G8-2 & 0.7093 & 142 & 0.0882 & 9 & 0.2571 & 544.3 & 16.9 & 545.1 & 10.8 \\
\hline 11 & $\mathrm{H} 2$ & 0.7165 & 171 & 0.0880 & 10 & 0.2413 & 548.6 & 20.2 & 543.9 & 12.0 \\
\hline 12 & $\mathrm{H} 4$ & 0.6902 & 447 & 0.0841 & 31 & 0.2842 & 532.9 & 53.7 & 520.6 & 36.8 \\
\hline 13 & H6 & 0.6859 & 844 & 0.0868 & 84 & 0.3944 & 530.3 & 101.6 & 536.9 & 100.0 \\
\hline 14 & $\mathrm{H} 7$ & 0.7130 & 347 & 0.0864 & 20 & 0.2354 & 546.5 & 41.1 & 534.3 & 23.5 \\
\hline 15 & H9 & 0.7248 & 127 & 0.0890 & 10 & 0.3094 & 553.5 & 15.0 & 549.6 & 11.4 \\
\hline 16 & H10 & 0.6981 & 557 & 0.0852 & 45 & 0.3283 & 537.7 & 66.7 & 527.3 & 53.1 \\
\hline 17 & H17 & 0.7149 & 737 & 0.0863 & 35 & 0.1993 & 547.7 & 87.3 & 533.9 & 42.1 \\
\hline 18 & $\mathrm{H} 21$ & 0.6795 & 365 & 0.0848 & 37 & 0.4031 & 526.4 & 44.2 & 524.5 & 43.7 \\
\hline 19 & $\mathrm{H} 22$ & 0.7336 & 678 & 0.0877 & 37 & 0.2288 & 558.7 & 79.4 & 542.2 & 44.0 \\
\hline 20 & $\mathrm{H} 24$ & 0.7142 & 158 & 0.0871 & 11 & 0.2769 & 547.2 & 18.8 & 538.3 & 12.7 \\
\hline 21 & $\mathrm{H} 25$ & 0.7208 & 644 & 0.0891 & 51 & 0.3232 & 551.1 & 76.0 & 550.0 & 60.9 \\
\hline 22 & $\mathrm{H} 26$ & 0.7129 & 315 & 0.0877 & 28 & 0.3641 & 546.4 & 37.3 & 541.9 & 33.4 \\
\hline DB66 & Scheggia diorite & & & & & & & & & \\
\hline 1 & $\mathrm{~J} 5$ & 0.6747 & 273 & 0.0845 & 28 & 0.4084 & 523.6 & 33.1 & 522.9 & 33.2 \\
\hline 2 & J6 & 0.7131 & 538 & 0.0853 & 43 & 0.3377 & 546.6 & 63.7 & 527.4 & 51.6 \\
\hline 3 & $\mathrm{~J} 7$ & 0.6777 & 836 & 0.0859 & 67 & 0.3184 & 525.4 & 101.2 & 531.3 & 80.1 \\
\hline 4 & $\mathrm{~J} 8$ & 0.6967 & 320 & 0.0837 & 29 & 0.3753 & 536.8 & 38.3 & 518.2 & 34.3 \\
\hline 5 & $\mathrm{~J} 11$ & 0.7335 & 428 & 0.0897 & 35 & 0.3343 & 558.6 & 50.2 & 554.0 & 41.5 \\
\hline 6 & $\mathrm{~J} 12$ & 0.7021 & 503 & 0.0841 & 36 & 0.2984 & 540.0 & 60.0 & 520.6 & 42.8 \\
\hline 7 & $\mathrm{~J} 13$ & 0.6568 & 586 & 0.0852 & 36 & 0.2368 & 512.7 & 71.9 & 526.9 & 42.8 \\
\hline
\end{tabular}


Table 2 continued

\begin{tabular}{|c|c|c|c|c|c|c|c|c|c|c|}
\hline Spot & Analyse number & ${ }^{207} \mathrm{~Pb} /{ }^{235} \mathrm{U}$ & $\pm 1 \sigma$ & ${ }^{206} \mathrm{~Pb} /{ }^{238} \mathrm{U}$ & $\pm 1 \sigma$ & Rho & $\begin{array}{l}{ }^{207} \mathrm{~Pb} /{ }^{235} \mathrm{U} \text { apparent } \\
\text { age (Ma) }\end{array}$ & $\pm 2 \sigma$ & $\begin{array}{l}{ }^{206} \mathrm{~Pb} /{ }^{238} \mathrm{U} \text { apparent } \\
\text { age (Ma) }\end{array}$ & $\pm 2 \sigma$ \\
\hline 8 & $\mathrm{~J} 14$ & 0.6768 & 421 & 0.0844 & 36 & 0.3458 & 524.9 & 51.0 & 522.2 & 43.2 \\
\hline 9 & $\mathrm{~J} 27$ & 0.7146 & 169 & 0.0880 & 13 & 0.3133 & 547.5 & 20.0 & 543.8 & 15.5 \\
\hline 10 & $\mathrm{~J} 28$ & 0.7193 & 383 & 0.0888 & 24 & 0.2561 & 550.3 & 45.2 & 548.6 & 28.7 \\
\hline 11 & $\mathrm{~J} 30$ & 0.6842 & 309 & 0.0848 & 23 & 0.2972 & 529.3 & 37.3 & 524.6 & 27.1 \\
\hline 12 & $\mathrm{~J} 31$ & 0.6961 & 382 & 0.0840 & 24 & 0.2599 & 536.4 & 45.7 & 520.0 & 28.5 \\
\hline 13 & $\mathrm{~J} 33$ & 0.6926 & 498 & 0.0855 & 50 & 0.4060 & 534.4 & 59.8 & 529.0 & 59.3 \\
\hline 14 & $\mathrm{~J} 34$ & 0.7176 & 443 & 0.0880 & 28 & 0.2552 & 549.2 & 52.4 & 543.5 & 32.9 \\
\hline 15 & $\mathrm{~J} 47$ & 0.6962 & 322 & 0.0840 & 32 & 0.4062 & 536.5 & 38.6 & 520.0 & 37.6 \\
\hline 16 & $\mathrm{~J} 50$ & 0.6799 & 341 & 0.0859 & 28 & 0.3226 & 526.7 & 41.2 & 531.4 & 33.0 \\
\hline 17 & $\mathrm{~K} 2$ & 0.6811 & 427 & 0.0853 & 41 & 0.3836 & 527.4 & 51.6 & 527.6 & 48.7 \\
\hline 18 & K9 & 0.6890 & 528 & 0.0863 & 49 & 0.3673 & 532.2 & 63.4 & 533.5 & 57.6 \\
\hline 19 & K11 & 0.7155 & 344 & 0.0866 & 26 & 0.3118 & 548.0 & 40.7 & 535.4 & 30.8 \\
\hline 20 & K13 & 0.7078 & 607 & 0.0872 & 60 & 0.4023 & 543.4 & 72.1 & 539.0 & 71.3 \\
\hline DB04 & Zött paragneiss & & & & & & & & & \\
\hline 1 & E1 & 0.6573 & 650 & 0.0813 & 46 & 0.2839 & 512.9 & 39.8 & 503.9 & 27.2 \\
\hline 2 & E4 & 0.6065 & 874 & 0.0734 & 59 & 0.2780 & 481.3 & 55.2 & 456.8 & 35.3 \\
\hline 3 & $\mathrm{E} 4-2$ & 0.6496 & 1,118 & 0.0772 & 49 & 0.1849 & 508.2 & 68.8 & 479.5 & 29.4 \\
\hline 4 & E7 & 0.6066 & 1,008 & 0.0777 & 73 & 0.2820 & 481.4 & 63.7 & 482.3 & 43.6 \\
\hline 5 & E7-2 & 0.5959 & 1,928 & 0.0701 & 203 & 0.4468 & 474.6 & 122.7 & 436.5 & 122.0 \\
\hline
\end{tabular}

Errors refer to last significant digits

about $10 \mathrm{~cm}$ to $1 \mathrm{~m}$ thick and are strongly folded and boudinaged, but schistosity is faint. Samples DB41 and DB42 are dark grey to greenish, relatively coarse-grained $(<4 \mathrm{~mm})$ due to abundant poikilitic porphyroblasts of amphibole and biotite. They have similar mineral assemblages, but in different modal proportions. K-feldspar, quartz, biotite, calcite, plagioclase $\left(\mathrm{An}_{33-11}\right)$, epidote, chlorite and white mica are the major phases. Accessories include ores, rutile, sphene, apatite and zircon. Narrow biotite-rich reaction rims are locally developed in the orthogneiss.

All these lamprophyres are of calc-alkaline type (Rock 1991; see also chemical data in Bussien et al. 2008b), characterized by low contents in $\mathrm{Na}_{2} \mathrm{O}, \mathrm{TiO}_{2}, \mathrm{P}_{2} \mathrm{O}_{5}$ and REE $(\mathrm{La}<33 \mathrm{ppm})$, relatively high contents in $\mathrm{SiO}_{2}$ (mostly above $50 \mathrm{wt} \%$ ) and often very high in $\mathrm{K}_{2} \mathrm{O}$ (up to $6.9 \mathrm{wt} \%$ ). However, their whole-rock chemical composition is quite variable (Table 1; Fig. 3). Normalized REE patterns display a similar shape, but spread out as a result of contrasting concentrations (e.g. 15-33 ppm La; Fig. 4). Eu anomalies are moderate (0.91-0.72). Chemical variation is ascribed to a combination of several factors, including magma differentiation, mineral accumulation (crystal mush) and secondary (hydrothermal and/or metamorphic) alteration like sericitization and carbonatation (see discussion in Bussien et al. 2008b).

\section{U-Pb zircon dating procedure}

Zircons were extracted using conventional heavy liquids and magnetic separation techniques after manual panning of the rock powder in soapy water. Gem quality grains were hand picked and treated according to the procedure of Mattinson (2005). They were thermally annealed at $850^{\circ} \mathrm{C}$ during $24 \mathrm{~h}$ in porcelain crucibles, then leached on a hot plate at $110^{\circ} \mathrm{C}$ in Savillex ${ }^{\circledR}$ beakers in a mixture of concentrated $\mathrm{HF}$ and $\mathrm{HNO}_{3}$ during $18 \mathrm{~h}$ and carefully rinsed with distilled water and alcohol in an ultrasonic bath. Selected grains were mounted in epoxy resin, abraded approximately to their equatorial plane and hand-polished using wet sand paper (granulometric class 2000) and diamond paste down to 1 micron in grain size. About 40 zircon grains from each sample were investigated through cathodoluminescence (CL) imaging (Fig. 5) by SEM at the University of Lausanne. All samples have been dated by laser ablation (LA) ICPMS technique at the Institute of Mineralogy and Geochemistry, University of Lausanne.

The analytical approach followed that outlined in Horn et al. (2000) and Kosler et al. (2002). We used a 193-nm Ar-F Geolas $200 \mathrm{M}$ excimer laser coupled to a Perkin Elmer Elan 6100 DRC ICPMS. We employed both spot and profiling techniques depending on zircon grain size and internal morphology. Profile analysis was systematically 
Table $3 \mathrm{U}-\mathrm{Pb}$ isotope data on zircons from Variscan granitoids of the Sambuco and Maggia nappes, and from a gneiss block at the Tamier Pass (LA-ICPMS, Univ. Lausanne)

\begin{tabular}{|c|c|c|c|c|c|c|c|c|c|c|}
\hline Spot & Analyse number & ${ }^{207} \mathrm{~Pb} /{ }^{235} \mathrm{U}$ & $\pm 1 \sigma$ & ${ }^{206} \mathrm{~Pb} /{ }^{238} \mathrm{U}$ & $\pm 1 \sigma$ & Rho & $\begin{array}{l}{ }^{207} \mathrm{~Pb} /{ }^{235} \mathrm{U} \text { apparent } \\
\text { age }(\mathrm{Ma})\end{array}$ & $\pm 2 \sigma$ & $\begin{array}{l}{ }^{206} \mathrm{~Pb} /{ }^{238} \mathrm{U} \text { apparent } \\
\text { age }(\mathrm{Ma})\end{array}$ & $\pm 2 \sigma$ \\
\hline
\end{tabular}

Variscan granitoids

DB77 Matorello granodiorite

\begin{tabular}{|c|c|c|c|c|c|c|c|c|c|c|}
\hline 1 & B4-3 & 0.3452 & 255 & 0.0473 & 25 & 0.3583 & 301.1 & 19.2 & 297.9 & 15.4 \\
\hline 2 & B5-3 & 0.3562 & 312 & 0.0484 & 33 & 0.3854 & 309.4 & 23.4 & 304.4 & 20.1 \\
\hline 3 & C1-2 & 0.3311 & 298 & 0.0457 & 35 & 0.4217 & 290.4 & 22.7 & 288.2 & 21.4 \\
\hline 4 & $\mathrm{C} 2-2$ & 0.3506 & 393 & 0.0468 & 45 & 0.4310 & 305.1 & 29.6 & 294.8 & 27.9 \\
\hline 5 & $\mathrm{C} 2-3$ & 0.3667 & 231 & 0.0484 & 22 & 0.3643 & 317.2 & 17.2 & 304.9 & 13.7 \\
\hline 6 & C3-2 & 0.3649 & 390 & 0.0486 & 50 & 0.4802 & 315.9 & 29.0 & 305.7 & 30.6 \\
\hline 7 & C4-2 & 0.3379 & 310 & 0.0465 & 36 & 0.4180 & 295.6 & 23.5 & 293.3 & 22.0 \\
\hline 8 & C4-4 & 0.3443 & 266 & 0.0468 & 29 & 0.3993 & 300.4 & 20.1 & 295.0 & 17.8 \\
\hline 9 & C5-2 & 0.3564 & 334 & 0.0475 & 39 & 0.4333 & 309.5 & 25.0 & 299.2 & 23.8 \\
\hline 10 & C6-2 & 0.3230 & 403 & 0.0442 & 53 & 0.4774 & 284.2 & 30.9 & 279.1 & 32.5 \\
\hline 11 & C7-3 & 0.3303 & 270 & 0.0457 & 32 & 0.4217 & 289.8 & 20.6 & 287.9 & 19.4 \\
\hline 12 & $\mathrm{C} 10$ & 0.3721 & 270 & 0.0500 & 35 & 0.4765 & 321.2 & 20.0 & 314.5 & 21.3 \\
\hline 13 & C11 & 0.3645 & 144 & 0.0484 & 14 & 0.3777 & 315.6 & 10.7 & 304.9 & 8.9 \\
\hline DB1C & \multicolumn{10}{|c|}{ Matorello granodiorite } \\
\hline 1 & G1 & 0.3648 & 417 & 0.0498 & 43 & 0.3762 & 315.8 & 62.1 & 313.4 & 52.7 \\
\hline 2 & G2 & 0.3439 & 386 & 0.0485 & 42 & 0.3830 & 300.1 & 58.4 & 305.4 & 51.3 \\
\hline 3 & G3-2 & 0.3440 & 567 & 0.0470 & 69 & 0.4464 & 300.2 & 85.6 & 296.4 & 85.2 \\
\hline 4 & G4 & 0.3479 & 405 & 0.0483 & 32 & 0.2804 & 303.1 & 61.0 & 303.9 & 38.8 \\
\hline 5 & G4-2 & 0.3596 & 553 & 0.0473 & 69 & 0.4745 & 311.9 & 82.6 & 297.8 & 84.9 \\
\hline 6 & G5 & 0.3802 & 355 & 0.0488 & 33 & 0.3604 & 327.2 & 52.2 & 307.1 & 40.4 \\
\hline 7 & G7 & 0.3602 & 301 & 0.0500 & 34 & 0.4082 & 312.4 & 45.0 & 314.6 & 42.0 \\
\hline 8 & G8 & 0.3493 & 253 & 0.0484 & 29 & 0.4130 & 304.2 & 38.0 & 304.4 & 35.5 \\
\hline 9 & G8-2 & 0.3440 & 353 & 0.0464 & 44 & 0.4597 & 300.2 & 53.4 & 292.6 & 54.1 \\
\hline 10 & H1 & 0.3630 & 553 & 0.0487 & 55 & 0.3734 & 314.5 & 82.6 & 306.8 & 68.4 \\
\hline 11 & $\mathrm{H} 2$ & 0.3600 & 363 & 0.0491 & 36 & 0.3622 & 312.2 & 54.4 & 308.8 & 44.2 \\
\hline 12 & $\mathrm{H} 3$ & 0.3702 & 360 & 0.0499 & 38 & 0.3902 & 319.8 & 53.5 & 313.7 & 46.6 \\
\hline 13 & H6 & 0.3634 & 410 & 0.0499 & 31 & 0.2779 & 314.8 & 61.3 & 314.0 & 38.6 \\
\hline 14 & $\mathrm{H} 7$ & 0.3732 & 489 & 0.0496 & 58 & 0.4496 & 322.0 & 72.5 & 312.1 & 72.0 \\
\hline 15 & H11 & 0.3719 & 277 & 0.0508 & 31 & 0.4030 & 321.1 & 41.2 & 319.6 & 37.6 \\
\hline 16 & H12 & 0.3414 & 385 & 0.0459 & 47 & 0.4571 & 298.2 & 58.4 & 289.4 & 58.5 \\
\hline 17 & I 2 & 0.3533 & 161 & 0.0480 & 14 & 0.3254 & 307.2 & 24.2 & 302.3 & 17.6 \\
\hline 18 & I3 & 0.3663 & 319 & 0.0502 & 25 & 0.2825 & 316.9 & 47.4 & 315.9 & 30.4 \\
\hline 19 & I4 & 0.3465 & 466 & 0.0486 & 57 & 0.4398 & 302.1 & 70.2 & 306.0 & 70.7 \\
\hline 20 & I5 & 0.3641 & 590 & 0.0488 & 61 & 0.3852 & 315.3 & 87.8 & 306.9 & 74.9 \\
\hline 21 & I7 & 0.3531 & 500 & 0.0458 & 56 & 0.4323 & 307.1 & 75.1 & 288.7 & 69.2 \\
\hline 22 & I13 & 0.3368 & 286 & 0.0438 & 28 & 0.3725 & 294.8 & 43.4 & 276.3 & 34.2 \\
\hline 23 & I15 & 0.3565 & 426 & 0.0463 & 30 & 0.2712 & 309.6 & 63.8 & 291.5 & 37.0 \\
\hline 24 & I 20 & 0.3490 & 493 & 0.0462 & 62 & 0.4774 & 304.0 & 74.3 & 290.9 & 76.8 \\
\hline 25 & $\mathrm{I} 22$ & 0.3528 & 331 & 0.0461 & 22 & 0.2538 & 306.8 & 49.7 & 290.3 & 27.1 \\
\hline 26 & I 23 & 0.3570 & 361 & 0.0468 & 29 & 0.3039 & 310.0 & 54.0 & 294.6 & 35.4 \\
\hline DB3C & \multicolumn{10}{|c|}{ Sassello gneiss } \\
\hline 1 & D1 & 0.3437 & 152 & 0.0471 & 13 & 0.3096 & 300.0 & 23.0 & 296.5 & 15.9 \\
\hline 2 & D1-2 & 0.3331 & 156 & 0.0464 & 11 & 0.2582 & 292.0 & 23.7 & 292.5 & 13.8 \\
\hline 3 & D2 & 0.3544 & 285 & 0.0472 & 16 & 0.2106 & 308.0 & 42.8 & 297.2 & 19.7 \\
\hline 4 & D4 & 0.3433 & 177 & 0.0479 & 12 & 0.2444 & 299.7 & 26.8 & 301.4 & 14.8 \\
\hline
\end{tabular}


Table 3 continued

\begin{tabular}{|c|c|c|c|c|c|c|c|c|c|c|}
\hline Spot & Analyse number & ${ }^{207} \mathrm{~Pb} /{ }^{235} \mathrm{U}$ & $\pm 1 \sigma$ & ${ }^{206} \mathrm{~Pb} /{ }^{238} \mathrm{U}$ & $\pm 1 \sigma$ & Rho & $\begin{array}{l}{ }^{207} \mathrm{~Pb} /{ }^{235} \mathrm{U} \text { apparent } \\
\text { age }(\mathrm{Ma})\end{array}$ & $\pm 2 \sigma$ & $\begin{array}{l}{ }^{206} \mathrm{~Pb} /{ }^{238} \mathrm{U} \text { apparent } \\
\text { age }(\mathrm{Ma})\end{array}$ & $\pm 2 \sigma$ \\
\hline 5 & D6 & 0.3413 & 212 & 0.0477 & 15 & 0.2557 & 298.2 & 32.1 & 300.3 & 18.7 \\
\hline 6 & D7 & 0.3564 & 253 & 0.0470 & 11 & 0.1683 & 309.6 & 37.9 & 296.2 & 13.9 \\
\hline 7 & D8 & 0.3417 & 100 & 0.0470 & 9 & 0.3315 & 298.5 & 15.1 & 296.0 & 11.2 \\
\hline 8 & D8-2 & 0.3495 & 241 & 0.0482 & 14 & 0.2166 & 304.4 & 36.3 & 303.2 & 17.7 \\
\hline 9 & D9 & 0.3366 & 147 & 0.0465 & 12 & 0.2936 & 294.6 & 22.3 & 293.1 & 14.7 \\
\hline 10 & D9-2 & 0.3252 & 178 & 0.0474 & 17 & 0.3307 & 285.9 & 27.3 & 298.4 & 21.2 \\
\hline 11 & D10 & 0.3565 & 188 & 0.0474 & 11 & 0.2106 & 309.6 & 28.1 & 298.8 & 13.0 \\
\hline 12 & D11 & 0.3422 & 182 & 0.0462 & 12 & 0.2342 & 298.9 & 27.5 & 291.3 & 14.2 \\
\hline 13 & D11-2 & 0.3296 & 230 & 0.0462 & 21 & 0.3293 & 289.3 & 35.1 & 291.1 & 26.1 \\
\hline 14 & D14 & 0.3607 & 164 & 0.0468 & 13 & 0.3013 & 312.7 & 24.4 & 294.8 & 15.8 \\
\hline 15 & D14-2 & 0.3510 & 196 & 0.0484 & 17 & 0.3211 & 305.5 & 29.4 & 304.9 & 21.4 \\
\hline 16 & D15 & 0.3465 & 143 & 0.0471 & 14 & 0.3576 & 302.1 & 21.5 & 296.9 & 17.1 \\
\hline DB23 & \multicolumn{10}{|c|}{ Laghetti granitic dyke } \\
\hline 1 & $\mathrm{D} 2$ & 0.3323 & 156 & 0.0458 & 15 & 0.3522 & 291.3 & 23.7 & 289.0 & 18.6 \\
\hline 2 & D4 & 0.3696 & 261 & 0.0502 & 21 & 0.2936 & 319.4 & 38.7 & 315.8 & 25.5 \\
\hline 3 & D5 & 0.3567 & 168 & 0.0479 & 11 & 0.2378 & 309.7 & 25.2 & 301.8 & 13.2 \\
\hline 4 & D5-2 & 0.3432 & 252 & 0.0479 & 17 & 0.2427 & 299.6 & 38.1 & 301.7 & 21.0 \\
\hline 5 & D7 & 0.3682 & 336 & 0.0499 & 21 & 0.2355 & 318.3 & 49.9 & 313.9 & 26.3 \\
\hline 6 & D8 & 0.3585 & 171 & 0.0494 & 21 & 0.4457 & 311.1 & 25.6 & 310.8 & 25.9 \\
\hline 7 & D8-2 & 0.3343 & 124 & 0.0463 & 15 & 0.4325 & 292.8 & 18.8 & 291.9 & 18.3 \\
\hline 8 & D8-3 & 0.3598 & 366 & 0.0498 & 37 & 0.3660 & 312.1 & 54.6 & 313.4 & 45.5 \\
\hline 9 & D9-2 & 0.3566 & 185 & 0.0479 & 20 & 0.4047 & 309.7 & 27.7 & 301.9 & 24.8 \\
\hline 10 & D11 & 0.3391 & 195 & 0.0468 & 15 & 0.2721 & 296.5 & 29.5 & 294.8 & 18.0 \\
\hline DB12 & \multicolumn{10}{|l|}{ Tamier gneiss } \\
\hline 1 & D1 & 0.3173 & 169 & 0.0447 & 15 & 0.3163 & 279.8 & 26.1 & 282.2 & 18.6 \\
\hline 2 & D1-2 & 0.3503 & 350 & 0.0474 & 34 & 0.3608 & 305.0 & 52.7 & 298.8 & 42.1 \\
\hline 3 & D2 & 0.3247 & 182 & 0.0463 & 17 & 0.3350 & 285.5 & 28.0 & 291.6 & 21.5 \\
\hline 4 & D3 & 0.3030 & 192 & 0.0444 & 12 & 0.2137 & 268.7 & 29.9 & 280.0 & 14.8 \\
\hline 5 & E1 & 0.3248 & 325 & 0.0449 & 24 & 0.2644 & 285.6 & 49.8 & 282.9 & 29.3 \\
\hline 6 & E3 & 0.3349 & 156 & 0.0467 & 16 & 0.3691 & 293.3 & 23.8 & 294.0 & 19.8 \\
\hline DB06 & \multicolumn{10}{|l|}{ Rüscada aplite } \\
\hline 1 & $\mathrm{G} 2$ & 0.3680 & 133 & 0.0498 & 17 & 0.4666 & 318.2 & 19.8 & 313.3 & 20.6 \\
\hline 2 & G5 & 0.3449 & 384 & 0.0451 & 31 & 0.3053 & 300.8 & 58.1 & 284.4 & 37.9 \\
\hline 3 & G6 & 0.3557 & 630 & 0.0476 & 78 & 0.4611 & 309.0 & 94.4 & 299.8 & 95.7 \\
\hline 4 & H3 & 0.3521 & 604 & 0.0477 & 81 & 0.4940 & 306.3 & 90.7 & 300.6 & 99.6 \\
\hline 5 & H17 & 0.3572 & 276 & 0.0477 & 34 & 0.4550 & 310.1 & 41.2 & 300.6 & 41.2 \\
\hline 6 & H19 & 0.3464 & 337 & 0.0459 & 41 & 0.4629 & 302.0 & 50.8 & 289.3 & 50.9 \\
\hline 7 & I1 & 0.3381 & 267 & 0.0454 & 33 & 0.4584 & 295.7 & 40.5 & 286.5 & 40.6 \\
\hline 8 & I1 & 0.3521 & 248 & 0.0473 & 31 & 0.4643 & 306.3 & 37.2 & 298.0 & 38.1 \\
\hline 9 & I32 & 0.3831 & 344 & 0.0498 & 35 & 0.3906 & 329.3 & 50.6 & 313.2 & 42.9 \\
\hline 10 & I34 & 0.3871 & 511 & 0.0536 & 69 & 0.4843 & 332.3 & 74.8 & 336.8 & 83.9 \\
\hline 11 & I36 & 0.3255 & 196 & 0.0446 & 25 & 0.4643 & 286.1 & 30.1 & 281.5 & 30.9 \\
\hline DB44 & \multicolumn{10}{|l|}{ Cocco granodiorite } \\
\hline 1 & G2 & 0.3505 & 527 & 0.0494 & 39 & 0.2644 & 305.1 & 79.2 & 311.0 & 48.3 \\
\hline 2 & $\mathrm{G} 2-2$ & 0.3518 & 248 & 0.0484 & 22 & 0.3183 & 306.1 & 37.4 & 304.9 & 26.8 \\
\hline 3 & G3 & 0.3692 & 370 & 0.0497 & 33 & 0.3330 & 319.1 & 54.9 & 312.4 & 40.7 \\
\hline 4 & G3-2 & 0.3689 & 423 & 0.0494 & 45 & 0.3943 & 318.8 & 62.7 & 310.9 & 54.8 \\
\hline 5 & G4 & 0.3562 & 346 & 0.0489 & 23 & 0.2456 & 309.4 & 51.8 & 307.9 & 28.7 \\
\hline
\end{tabular}


Table 3 continued

\begin{tabular}{|c|c|c|c|c|c|c|c|c|c|c|}
\hline Spot & Analyse number & ${ }^{207} \mathrm{~Pb} /{ }^{235} \mathrm{U}$ & $\pm 1 \sigma$ & ${ }^{206} \mathrm{~Pb} /{ }^{238} \mathrm{U}$ & $\pm 1 \sigma$ & Rho & $\begin{array}{l}{ }^{207} \mathrm{~Pb} /{ }^{235} \mathrm{U} \text { apparent } \\
\text { age (Ma) }\end{array}$ & $\pm 2 \sigma$ & $\begin{array}{l}{ }^{206} \mathrm{~Pb} /{ }^{238} \mathrm{U} \text { apparent } \\
\text { age }(\mathrm{Ma})\end{array}$ & $\overline{ \pm 2 \sigma}$ \\
\hline 6 & G4-2 & 0.3510 & 317 & 0.0492 & 31 & 0.3504 & 305.5 & 47.7 & 309.7 & 38.3 \\
\hline 7 & G5-2 & 0.3618 & 329 & 0.0488 & 37 & 0.4139 & 313.6 & 49.1 & 307.2 & 45.2 \\
\hline 8 & G6 & 0.3821 & 284 & 0.0506 & 25 & 0.3284 & 328.6 & 41.7 & 317.9 & 30.3 \\
\hline 9 & G7 & 0.3458 & 324 & 0.0474 & 26 & 0.2915 & 301.5 & 48.8 & 298.3 & 31.8 \\
\hline 10 & G7-2 & 0.3322 & 508 & 0.0467 & 37 & 0.2579 & 291.3 & 77.5 & 294.2 & 45.4 \\
\hline 11 & G8 & 0.3635 & 493 & 0.0486 & 59 & 0.4441 & 314.8 & 73.5 & 305.7 & 72.0 \\
\hline 12 & G8-2 & 0.3720 & 321 & 0.0491 & 21 & 0.2472 & 321.1 & 47.6 & 308.8 & 25.8 \\
\hline 13 & G9 & 0.3464 & 283 & 0.0482 & 33 & 0.4183 & 302.0 & 42.6 & 303.4 & 40.5 \\
\hline 14 & G9-2 & 0.3354 & 463 & 0.0465 & 45 & 0.3493 & 293.7 & 70.4 & 293.2 & 55.3 \\
\hline 15 & G10 & 0.3501 & 327 & 0.0474 & 38 & 0.4327 & 304.8 & 49.2 & 298.4 & 47.1 \\
\hline 16 & G11 & 0.3665 & 384 & 0.0494 & 24 & 0.2280 & 317.1 & 57.0 & 311.0 & 29.0 \\
\hline 17 & G11-2 & 0.3559 & 435 & 0.0482 & 50 & 0.4258 & 309.1 & 65.1 & 303.3 & 61.6 \\
\hline 18 & G12 & 0.3464 & 337 & 0.0482 & 34 & 0.3636 & 302.0 & 50.8 & 303.5 & 42.0 \\
\hline 19 & G12-2 & 0.3577 & 343 & 0.0489 & 20 & 0.2147 & 310.5 & 51.3 & 307.9 & 24.7 \\
\hline 20 & G13 & 0.3358 & 313 & 0.0459 & 36 & 0.4236 & 294.0 & 47.6 & 289.2 & 44.7 \\
\hline 21 & G14 & 0.3772 & 343 & 0.0513 & 40 & 0.4285 & 325.0 & 50.6 & 322.2 & 49.0 \\
\hline 22 & G14-2 & 0.3621 & 407 & 0.0490 & 42 & 0.3769 & 313.8 & 60.7 & 308.5 & 51.1 \\
\hline 23 & G15-2 & 0.3680 & 311 & 0.0504 & 35 & 0.2676 & 318.2 & 46.0 & 317.2 & 24.0 \\
\hline 24 & $\mathrm{H} 2$ & 0.3567 & 338 & 0.0481 & 41 & 0.4537 & 309.7 & 50.7 & 302.8 & 50.9 \\
\hline 25 & H4 & 0.3517 & 387 & 0.0489 & 36 & 0.3384 & 306.0 & 58.2 & 308.1 & 44.9 \\
\hline 26 & H6 & 0.3690 & 527 & 0.0497 & 37 & 0.2640 & 318.9 & 78.2 & 312.9 & 46.1 \\
\hline 27 & $\mathrm{H} 7$ & 0.3482 & 323 & 0.0485 & 34 & 0.3729 & 303.4 & 48.7 & 305.1 & 41.2 \\
\hline
\end{tabular}

Errors refer to last significant digits

preferred when applicable. Generally, profile analysis comprised 1400 readings (including ca. 350 blank readings) collected using a laser beam fluence of ca. $6.5 \mathrm{~J} / \mathrm{cm}^{2}$ at a frequency of $10 \mathrm{~Hz}$. Profile beam diameter and length of path varied between 20 and $30 \mu \mathrm{m}$ and $100-180 \mu \mathrm{m}$, respectively. Spot analysis involved 700 readings (including ca. 200 blank readings) with the same energy and a frequency of $4 \mathrm{~Hz}$. Larger beam diameter of $40 \mu \mathrm{m}$ resulted in signal levels comparable to profiling with slightly worse signal stability and small but gradual decrease in sensitivity toward the end of the individual spot analysis. Instrumental mass bias was corrected using a Tl-U spike $\left({ }^{203} \mathrm{Tl}^{-205} \mathrm{Tl}^{233} \mathrm{U}-{ }^{236} \mathrm{U}\right.$; natural ${ }^{205} \mathrm{Tl} /{ }^{203} \mathrm{Tl}=$ 2.3871; ${ }^{233} \mathrm{U}^{236} \mathrm{U}=0.8450$ ) (Kosler et al. 2002) mixed online with sample aerosol prior to injection into the plasma. The spike was diluted to a ${ }^{233} \mathrm{U}$ concentration of $250 \mathrm{ppt}$ and aspirated at a rate of ca. $30 \mu \mathrm{l} / \mathrm{mn}$ through a micro-injector using a argon gas flow of ca. $0.5 \mathrm{l} / \mathrm{mn}$ into an Apex ${ }^{\circledR}$ desolvator, an additional 0.09 1/mn argon flow was injected at the outlet of the desolvator, prior to mixing with the sample aerosol, carried in a $1.1 \mathrm{l} / \mathrm{mn}$ helium flow. ICPMS settings were the following: RF power $1,350 \mathrm{~W}$, plasma gas flow $15.25 \mathrm{l} / \mathrm{mn}$, auxiliary gas flow $1.051 / \mathrm{mn}$, pulse mode, autolens on. The following masses were measured sequentially: ${ }^{201} \mathrm{Hg}$, ${ }^{202} \mathrm{Hg},{ }^{203} \mathrm{Tl},{ }^{204} \mathrm{~Pb},{ }^{205} \mathrm{Tl},{ }^{206} \mathrm{~Pb},{ }^{207} \mathrm{~Pb},{ }^{233} \mathrm{U},{ }^{235} \mathrm{U},{ }^{236} \mathrm{U}$, ${ }^{238} \mathrm{U},{ }^{249} \mathrm{UO},{ }^{252} \mathrm{UO}$ and ${ }^{254} \mathrm{UO}$. Oxides have been reconverted to elemental intensities and added to the corresponding isotopes. No common $\mathrm{Pb}$ correction was applied considering the very low ${ }^{204} \mathrm{~Pb}$ intensities and its negligible effect on the final ages in view of their large individual uncertainties.

A typical run includes 6 measurements of the Plesovice zircon standard (used as a mass-bias monitor), 10 unknowns, 4 measurements on the 91500 zircon standard (used as a monitor for external reproducibility, i.e. accuracy of the data), 10 unknowns and again 6 measurements on Plesovice, which are also used as the first 6 acquisitions of the subsequent run. Long-term monitoring showed that instrumental mass bias was fluctuating on a day to day basis, and also within a session, especially when the instrument had just been thoroughly cleaned. The raw data were processed offline in a two-step procedure with the LAMDATE program written by J. Kosler (Memorial University of Newfoundland, St. Johns). In a first step, the mean ${ }^{206} \mathrm{~Pb} /{ }^{238} \mathrm{U}$ isotopic ratio of the 12 Plesovice measurements of a run was used to adjust the current fractionation factor of the 
Table $4 \mathrm{U}-\mathrm{Pb}$ isotope data on zircons from Variscan lamprophyres (LA-ICPMS, Univ. Lausanne)

\begin{tabular}{|c|c|c|c|c|c|c|c|c|c|c|}
\hline Spot & Analyse number & ${ }^{207} \mathrm{~Pb} /{ }^{235} \mathrm{U}$ & $\pm 1 \sigma$ & ${ }^{206} \mathrm{~Pb} /{ }^{238} \mathrm{U}$ & $\pm 1 \sigma$ & Rho & $\begin{array}{l}{ }^{207} \mathrm{~Pb} /{ }^{235} \mathrm{U} \text { apparent } \\
\text { age }(\mathrm{Ma})\end{array}$ & $\pm 2 \sigma$ & $\begin{array}{l}{ }^{206} \mathrm{~Pb} /{ }^{238} \mathrm{U} \text { apparent } \\
\text { age (Ma) }\end{array}$ & $\pm 2 \sigma$ \\
\hline \multicolumn{11}{|c|}{ Variscan lamprophyres } \\
\hline DB76 & \multicolumn{10}{|c|}{ Laghetti lamprophyre } \\
\hline 1 & A1 & 0.3368 & 137 & 0.0470 & 15 & 0.3995 & 294.8 & 10.4 & 296.4 & 9.4 \\
\hline 2 & A1-4 & 0.3379 & 639 & 0.0456 & 76 & 0.4386 & 295.6 & 48.5 & 287.7 & 46.7 \\
\hline 3 & $\mathrm{~A} 2$ & 0.3543 & 292 & 0.0486 & 31 & 0.3813 & 307.9 & 21.9 & 305.9 & 18.8 \\
\hline 4 & A2-2 & 0.3835 & 485 & 0.0493 & 51 & 0.4082 & 329.6 & 35.6 & 310.1 & 31.3 \\
\hline DB29 & \multicolumn{10}{|c|}{ Sassello lamprophyre } \\
\hline 1 & D1 & 0.3575 & 263 & 0.0475 & 27 & 0.3851 & 310.3 & 39.3 & 299.0 & 33.1 \\
\hline 2 & D2 & 0.3395 & 161 & 0.0470 & 11 & 0.2478 & 296.8 & 24.4 & 296.0 & 13.6 \\
\hline 3 & D2-2 & 0.3389 & 285 & 0.0474 & 16 & 0.1959 & 296.4 & 43.2 & 298.7 & 19.2 \\
\hline 4 & D3 & 0.3343 & 114 & 0.0459 & 12 & 0.3938 & 292.9 & 17.4 & 289.3 & 15.2 \\
\hline 5 & D3-2 & 0.3512 & 131 & 0.0460 & 12 & 0.3513 & 305.6 & 19.7 & 290.2 & 14.9 \\
\hline 6 & D4 & 0.3352 & 150 & 0.0463 & 12 & 0.2976 & 293.5 & 22.8 & 292.1 & 15.2 \\
\hline 7 & E1 & 0.3451 & 128 & 0.0485 & 11 & 0.2974 & 301.0 & 19.3 & 305.4 & 13.2 \\
\hline 8 & E3-2 & 0.3576 & 294 & 0.0494 & 21 & 0.2552 & 310.4 & 44.0 & 310.8 & 25.5 \\
\hline 9 & E4-2 & 0.3468 & 195 & 0.0485 & 12 & 0.2206 & 302.3 & 29.3 & 305.6 & 14.8 \\
\hline 10 & E5 & 0.3312 & 248 & 0.0473 & 26 & 0.3604 & 290.5 & 37.8 & 298.0 & 31.4 \\
\hline 11 & E5-2 & 0.3198 & 288 & 0.0447 & 18 & 0.2237 & 281.7 & 44.4 & 281.9 & 22.3 \\
\hline 12 & E6 & 0.3312 & 134 & 0.0464 & 11 & 0.3028 & 290.5 & 20.4 & 292.1 & 14.0 \\
\hline 13 & E7 & 0.3456 & 400 & 0.0481 & 24 & 0.2187 & 301.4 & 60.4 & 302.7 & 30.0 \\
\hline 14 & E7-2 & 0.3489 & 329 & 0.0478 & 24 & 0.2709 & 303.9 & 49.5 & 300.9 & 30.0 \\
\hline 15 & E9 & 0.3355 & 403 & 0.0485 & 18 & 0.1565 & 293.8 & 61.2 & 305.5 & 22.4 \\
\hline DB41 & \multicolumn{10}{|c|}{ Tamier lamprophyre } \\
\hline 1 & $\mathrm{~A} 3$ & 0.3385 & 589 & 0.0483 & 61 & 0.3648 & 296.0 & 89.4 & 304.2 & 75.5 \\
\hline 2 & A3-2 & 0.3372 & 455 & 0.0471 & 39 & 0.3102 & 295.0 & 69.1 & 296.4 & 48.5 \\
\hline 3 & A4-2 & 0.3361 & 217 & 0.0457 & 19 & 0.3191 & 294.2 & 33.0 & 288.4 & 23.3 \\
\hline 4 & A5 & 0.3345 & 396 & 0.0467 & 27 & 0.2474 & 293.0 & 60.2 & 294.2 & 33.7 \\
\hline 5 & A6 & 0.3312 & 441 & 0.0458 & 47 & 0.3842 & 290.5 & 67.3 & 288.5 & 57.7 \\
\hline 6 & A6-2 & 0.3272 & 665 & 0.0458 & 62 & 0.3315 & 287.4 & 101.8 & 288.6 & 76.1 \\
\hline 7 & A7 & 0.3576 & 401 & 0.0488 & 23 & 0.2100 & 310.4 & 60.0 & 307.1 & 28.3 \\
\hline 8 & A7-2 & 0.3186 & 384 & 0.0441 & 34 & 0.3242 & 280.8 & 59.1 & 278.4 & 42.6 \\
\hline 9 & A7-3 & 0.3332 & 337 & 0.0463 & 26 & 0.2798 & 292.0 & 51.3 & 291.5 & 32.3 \\
\hline 10 & A9 & 0.3234 & 542 & 0.0455 & 50 & 0.3291 & 284.5 & 83.2 & 286.7 & 61.9 \\
\hline 11 & A11 & 0.3537 & 358 & 0.0468 & 28 & 0.2965 & 307.5 & 53.6 & 294.9 & 34.6 \\
\hline 12 & A14 & 0.3586 & 392 & 0.0486 & 17 & 0.1639 & 311.2 & 58.6 & 306.2 & 21.4 \\
\hline 13 & $\mathrm{C} 1$ & 0.3266 & 231 & 0.0454 & 15 & 0.2401 & 287.0 & 35.4 & 286.0 & 19.0 \\
\hline 14 & $\mathrm{C} 1-2$ & 0.3184 & 395 & 0.0449 & 39 & 0.3481 & 280.6 & 60.9 & 283.0 & 47.9 \\
\hline 15 & $\mathrm{C} 2$ & 0.3229 & 215 & 0.0447 & 11 & 0.1842 & 284.1 & 33.0 & 281.7 & 13.5 \\
\hline 16 & $\mathrm{C} 3$ & 0.3341 & 281 & 0.0442 & 13 & 0.1760 & 292.7 & 42.7 & 279.0 & 16.1 \\
\hline 17 & $\mathrm{C} 3-2$ & 0.3353 & 409 & 0.0448 & 23 & 0.2068 & 293.6 & 62.2 & 282.2 & 27.9 \\
\hline DB42 & \multicolumn{10}{|c|}{ Tamier lamprophyre } \\
\hline 1 & $\mathrm{~A} 2$ & 0.3299 & 210 & 0.0452 & 13 & 0.2302 & 289.5 & 32.1 & 284.8 & 16.4 \\
\hline 2 & A3-2 & 0.3086 & 386 & 0.0448 & 46 & 0.4090 & 273.1 & 59.9 & 282.8 & 56.6 \\
\hline 3 & A4-2 & 0.3379 & 453 & 0.0467 & 47 & 0.3730 & 295.6 & 68.7 & 294.1 & 57.5 \\
\hline 4 & A5 & 0.3235 & 235 & 0.0447 & 30 & 0.4550 & 284.6 & 36.0 & 282.0 & 36.4 \\
\hline 5 & A7 & 0.3283 & 250 & 0.0449 & 28 & 0.4145 & 288.3 & 38.2 & 283.3 & 35.0 \\
\hline 6 & C1-2 & 0.3394 & 179 & 0.0461 & 20 & 0.4210 & 296.7 & 27.1 & 290.7 & 25.2 \\
\hline 7 & $\mathrm{C} 1-3$ & 0.3274 & 233 & 0.0463 & 28 & 0.4226 & 287.6 & 35.7 & 291.7 & 34.4 \\
\hline
\end{tabular}


Table 4 continued

\begin{tabular}{ccccccccccc}
\hline Spot & Analyse number & ${ }^{207} \mathrm{~Pb} /{ }^{235} \mathrm{U}$ & $\pm 1 \sigma$ & ${ }^{206} \mathrm{~Pb} /{ }^{238} \mathrm{U}$ & $\pm 1 \sigma$ & $\mathrm{Rho}$ & $\begin{array}{l}{ }^{207} \mathrm{~Pb} /{ }^{235} \mathrm{U} \text { apparent } \\
\text { age (Ma) }\end{array}$ & $\begin{array}{c} \pm 2 \sigma \\
\text { age (Ma) }\end{array}$ & $\begin{array}{c}{ }^{206} \mathrm{~Pb} /{ }^{238} \mathrm{U} \text { apparent } \\
\text { agen }\end{array}$ \\
\hline 8 & $\mathrm{C} 1-4$ & 0.3319 & 571 & 0.0458 & 76 & 0.4819 & 291.0 & 87.1 & 288.8 \\
\hline
\end{tabular}

Errors refer to last significant digits
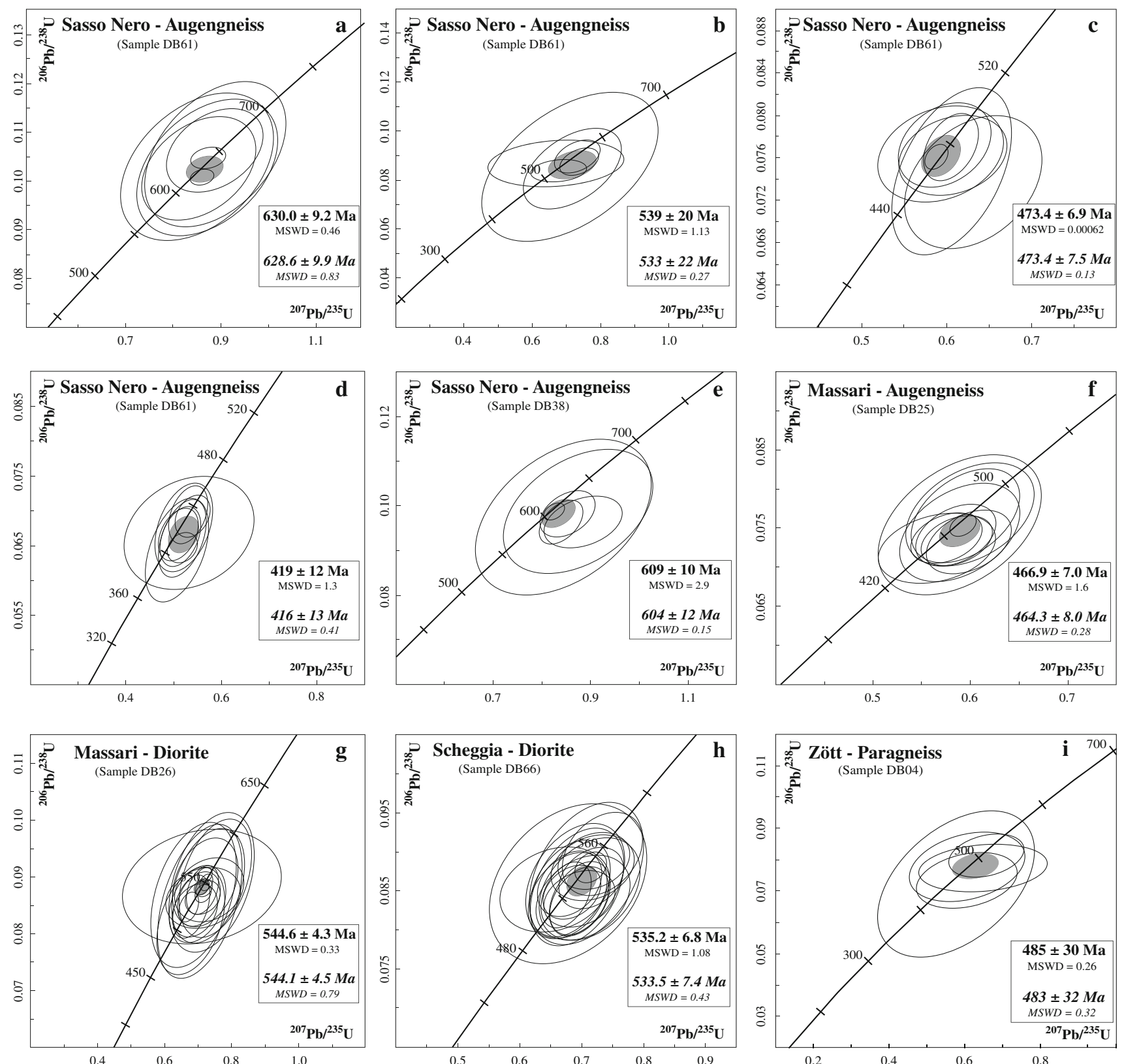

Fig. $6 \mathrm{U}-\mathrm{Pb}$ Concordia diagrams of the pre-Carboniferous rocks. Individual error ellipses are given at the 1-sigma level and errors on all calculated ages at the 2-sigma level (grey ellipse). The upper

instrument expressed by the ${ }^{205} \mathrm{Tl} /{ }^{236} \mathrm{U}$ ratio. In a second step, this factor was applied to the unknowns and the 91500 monitor, after background and laser-induced framed age is the Concordia age (Ludwig 2003) and the lower framed age (in italics) is the weighted average ${ }^{206} \mathrm{~Pb} /{ }^{238} \mathrm{U}$ age

fractionation correction (Kosler et al. 2002). In the LAMDATE program, the laser-induced fractionation is corrected by extrapolation of the measured isotopic ratios 

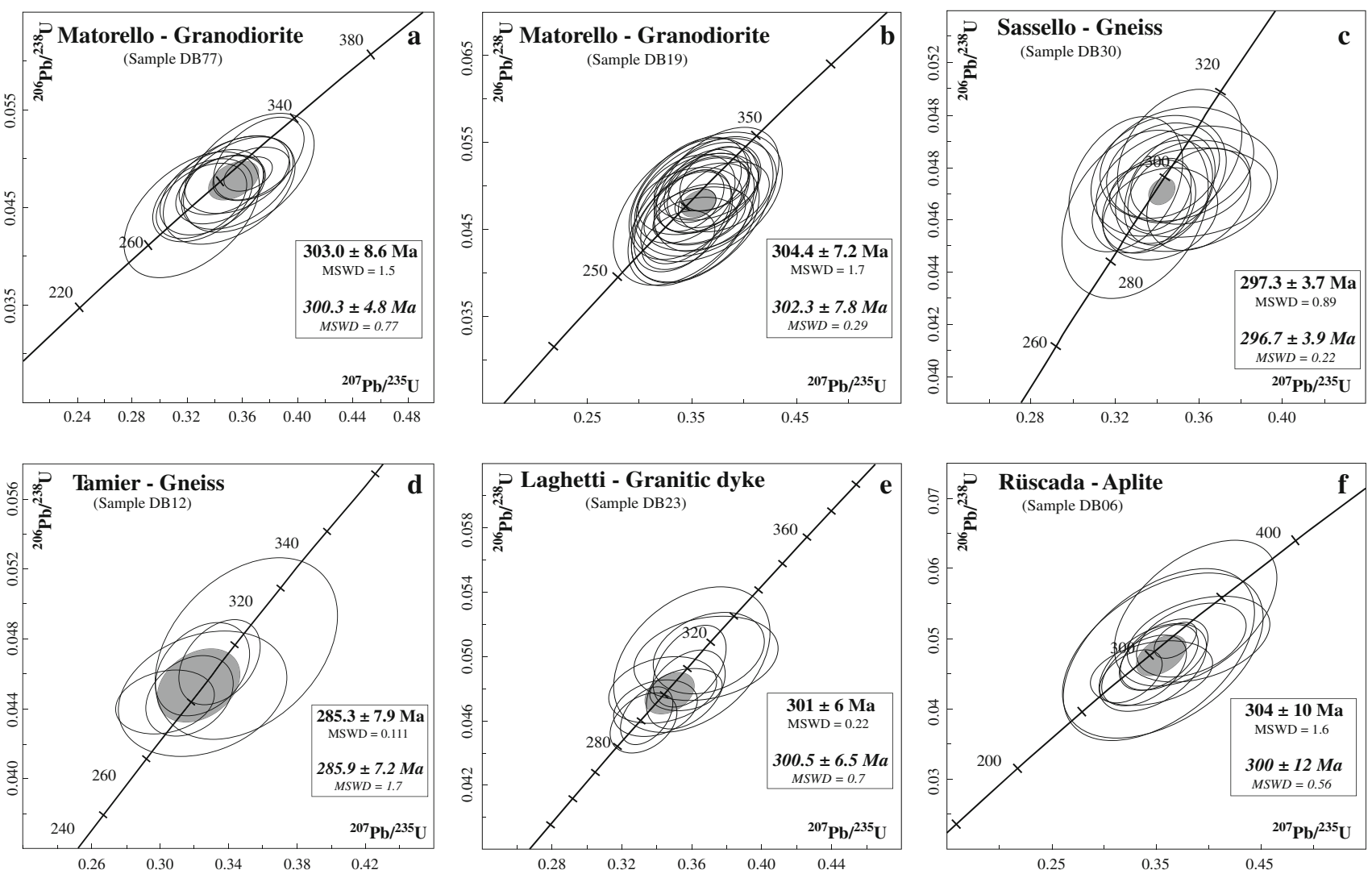

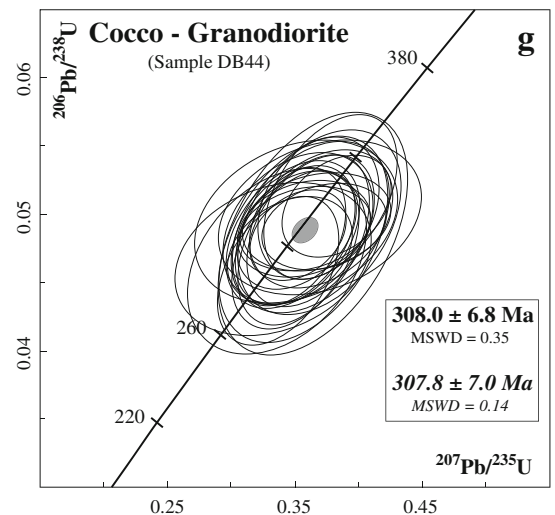

Fig. $7 \mathrm{U}-\mathrm{Pb}$ Concordia diagrams of the Variscan granitoids. Individual error ellipses are given at the 1-sigma level and errors on all calculated ages at the 2-sigma level (grey ellipse). The upper framed

to time zero (i.e. intercept values at $\mathrm{t}=0$ of best fit regression lines in time vs. intensity ratio diagrams).

Typical internal precision on standards varied between 2 to $7 \%$ (1 sigma) for the calculated ${ }^{207} \mathrm{~Pb} /{ }^{235} \mathrm{U}$ and ${ }^{206} \mathrm{~Pb} /{ }^{238} \mathrm{U}$ ages, and was independent of applied measurement mode. Typical mean ages obtained for 91500 zircon standard during a daily session were $1,069.4 \pm 5.9 \mathrm{Ma}(2 \sigma, 23$ analyses) in profile mode and 1,067.0 \pm 9.7 $\mathrm{Ma}(2 \sigma, 14$ analyses $)$ in spot mode, which are identical within analytical uncertainty to the certified age of $1,065.4 \pm 0.3 \mathrm{Ma}$ (Wiedenbeck et al. age is the Concordia age (Ludwig 2003) and the lower framed age (in italics) is the weighted average ${ }^{206} \mathrm{~Pb} /{ }^{238} \mathrm{U}$ age

1995). The corresponding Concordia age calculated for the Plesovice zircon standard was $337.8 \pm 1.9$ Ma $(2 \sigma, 34$ analyses), instead of $337.13 \pm 0.37 \mathrm{Ma}$ (Sláma et al. 2008). This slight age difference is related to the involvement of the ${ }^{207} \mathrm{~Pb} /{ }^{235} \mathrm{U}$ isotopic ratio in the Concordia age calculation, which is not taken into account during the first step of the data processing procedure.

Despite the use of the 91500 standard zircon as an accuracy monitor, results on individual zircon measurements are somehow user dependent, which undeniably 

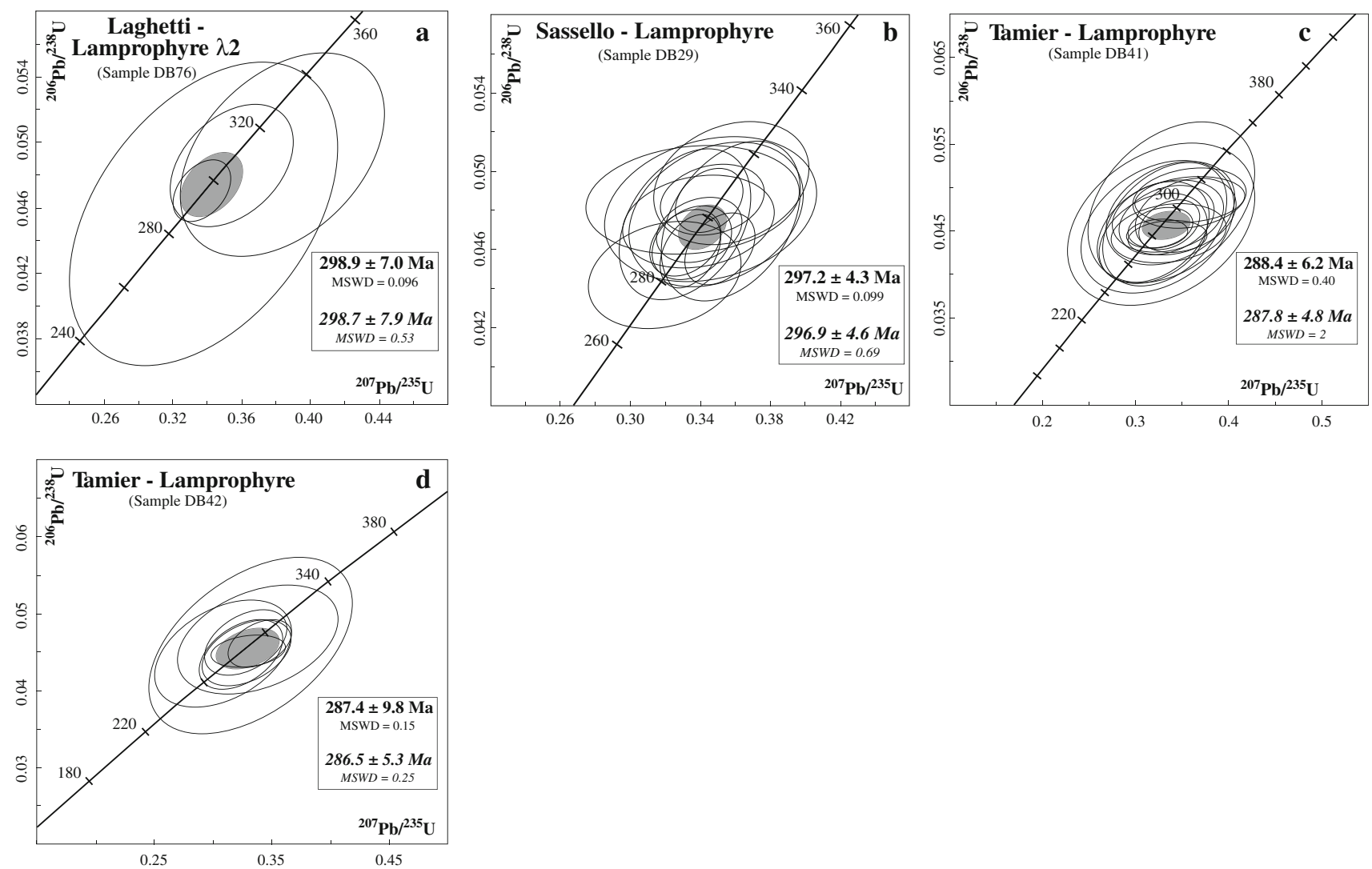

Fig. $8 \mathrm{U}-\mathrm{Pb}$ Concordia diagrams of the Variscan lamprophyres. Individual error ellipses are given at the 1-sigma level and errors on all calculated ages at the 2-sigma level (grey ellipse). The upper

represents a weakness of the procedure. Indeed, the laserinduced fractionation correction is made on the basis of a time resolved plot featuring the intensity ratios of the measured isotopes versus time. The user has to set manually the lower and upper boundaries of the ablation signal before the software automatically corrects the data for fractionation (slope correction). Experience shows that the final results are sensitive to the selected position of the boundaries in case of unstable signal; ${ }^{206} \mathrm{~Pb} /{ }^{238} \mathrm{U}$ ages can vary by up to $3 \%$ in the worst cases. Consequently, reliable ages can only be obtained by a large number of measurements.

\section{Results}

We decided to report in the tables and figures only concordant or sub-concordant measurements defining clusters on the Concordia line. We discarded all clearly discordant points, ascribed to mixing with an inherited fraction. Isolated concordant points older than cluster ages are not shown, but are mentioned as inherited cores in the text. A few concordant data significantly younger than the clusters

framed age is the Concordia age (Ludwig 2003) and the lower framed age (in italics) is the weighted average ${ }^{206} \mathrm{~Pb} /{ }^{238} \mathrm{U}$ age

within errors have been interpreted as affected by residual lead loss and ignored. Results are reported in Tables 2, 3 and 4 and displayed on Concordia diagrams in Figs. 6, 7 and 8 . Because ${ }^{207} \mathrm{~Pb} /{ }^{235} \mathrm{U}$ isotopic ratios are far less reliable than ${ }^{206} \mathrm{~Pb} /{ }^{238} \mathrm{U}$ ones due to much lower measured intensities, we reported both Concordia ages (ConcAge option of Isoplot/Ex, Ludwig 2003) and weighed average ${ }^{206} \mathrm{~Pb} /{ }^{238} \mathrm{U}$ ages. The latter are more reliable and display slightly more conservative uncertainties; only those will be further considered in the text and summarised in Table 5.

\subsection{The banded mafic complex of Alpe Scheggia}

Selected zircons from diorite samples DB26 and DB66 are prism fragments larger than 200 microns in their smallest dimension. They are characterized by simple cathodoluminescence (CL) structures consisting of large alternating bands parallel to the prism elongation and/or of sector zones (Fig. 5a, b). Grains are usually surrounded by a thin and sinuous ribbon of metamorphic origin. No inherited core has been observed. The large size and homogeneity of the grains yielded stable signals and concordant results (Table 1). DB26 gave a weighed average ${ }^{206} \mathrm{~Pb} /{ }^{238} \mathrm{U}$ age of 
Table 5 Summary of the weighed average ${ }^{206} \mathrm{~Pb} /{ }^{238} \mathrm{U}$ ages (this study) with their interpretation

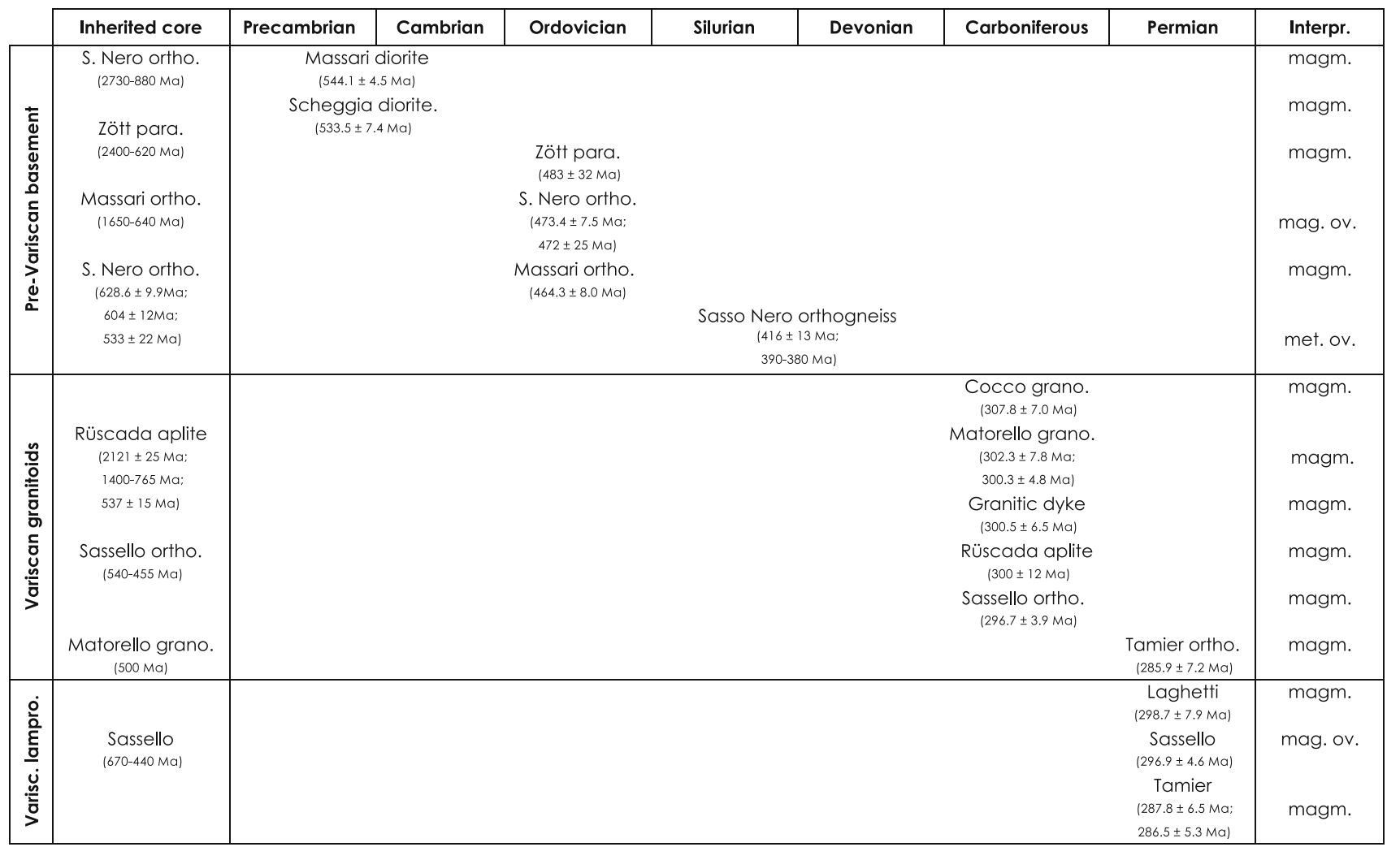

magm. magmatic, mag. ov. magmatic overgrowth, met. ov. metamorphic overgrowth, dio. diorite, grano. granodiorite, ortho. orthogneiss, para. paragneiss, S Nero Sasso Nero

$544.1 \pm 4.5 \mathrm{Ma}(22$ points; MSWD $=0.79)$ and DB66 an age of $533.5 \pm 7.4 \mathrm{Ma} \quad(20$ points; $\mathrm{MSWD}=0.43$; Fig. 6), both interpreted as magmatic ages.

\subsection{The older orthogneisses}

Zircons from the fine-grained orthogneiss DB25 at Alpe Massari are elongated, pinkish and of gem-quality. CL images reveal a nice oscillatory zoning of magmatic origin, few inherited cores and a discontinuous and narrow metamorphic fringe (Fig. 5c). Three inherited cores (data not reported) gave ${ }^{206} \mathrm{~Pb} /{ }^{238} \mathrm{U}$ ages of $1,650,730$ and $640 \mathrm{Ma}$, respectively. Ten measurements made on oscillatory zoned areas define a weighed average ${ }^{206} \mathrm{~Pb} /{ }^{238} \mathrm{U}$ age of $464.3 \pm 8.0 \mathrm{Ma}(\mathrm{MSWD}=0.28$; Fig. 6), interpreted as the magmatic crystallization age of the metagranite.

Samples DB38 and DB61 from the coarse-grained augengneiss of Sasso Nero supplied few zircons with blunt edges and complicated internal CL patterns. A typical grain consists in a resorbed core with dark CL zoning rimmed by a zone with oscillatory zoning, either normal or bright with faint structures (Fig. 5d). Results spread over a large range of concordant ages from 2,730 Ma down to $380 \mathrm{Ma}$ and cluster in several groups. The oldest dispersed ${ }^{206} \mathrm{~Pb} /{ }^{238} \mathrm{U}$ ages-2,730, 2,250, 1,780, 1,075, 1,000, $880 \mathrm{Ma}$-are all core data, mostly from DB61. A first consistent group of core data clusters at $604 \pm 12 \mathrm{Ma}$ in DB38 and $628.6 \pm 9.9 \mathrm{Ma}$ in DB61 (Fig. 6). A second group of core data stands out at $533 \pm 22 \mathrm{Ma}$ in DB61. A third group can be isolated in DB61 at a weighed average ${ }^{206} \mathrm{~Pb} /{ }^{238} \mathrm{U}$ age of $473.4 \pm 7.5 \mathrm{Ma}$ (7 points; MSWD $=0.13$ ); it corresponds to ablation of normal oscillatory growth zones, excluding resorbed cores (Fig. 5e). A set of four measurements from DB38 yield a similar mean age of $472 \pm 25 \mathrm{Ma}$ (MSWD = 0.065; not shown). Finally, a consistent group of 11 points from DB61 define a weighed average ${ }^{206} \mathrm{~Pb} /{ }^{238} \mathrm{U}$ age of $416 \pm 13 \mathrm{Ma} \quad(\mathrm{MSWD}=$ 0.41). They correspond to ablation of peripheral growth zones with more or less bright and faint CL structures. A few measurements on similar zones yielded even younger ages around 380-390 Ma. Zircon L10 from sample DB61 illustrates the complexity of age distribution (Fig. 5d). Besides an old core at ca. $630 \mathrm{Ma}$, the same bright growth zone yielded two contrasting, but concordant ages at $519 \pm 18$ and $381 \pm 12 \mathrm{Ma}$, respectively. This example shows that peripheral measurements on bright CL zones are dubious and might be geologically meaningless. 


\subsection{The Zött paragneiss}

Paragneiss sample DB04 from Lake Zött yielded a few zircons with a rounded outline. CL structures reveal some inherited resorbed cores, oscillatory growth zones and a thin irregular recrystallized rim of metamorphic origin. The results include (sub-) concordant ages at 2,400, 1,600 and $620 \mathrm{Ma}$, as well as a group of five measurements defining a weighed average ${ }^{206} \mathrm{~Pb} /{ }^{238} \mathrm{U}$ age of $483 \pm 32 \mathrm{Ma}(\mathrm{MSWD}=0.32)$.

\subsection{The Variscan granitoids}

The three granodiorite samples DB19, DB23 and DB77 from the Matorello intrusion have very similar prismatic zircons with a well-developed and delicate oscillatory zoning. A total of 26 measurements from sample DB19 define a weighed average ${ }^{206} \mathrm{~Pb} /{ }^{238} \mathrm{U}$ age of $302.3 \pm 7.8 \mathrm{Ma}$ (MSWD = 0.29; Fig. 7). One core has been observed and dated at ca. $500 \mathrm{Ma}$. Ten zircons from sample DB23 define a weighed average ${ }^{206} \mathrm{~Pb} /{ }^{238} \mathrm{U}$ age of $300.5 \pm 6.5 \mathrm{Ma}$ $(\mathrm{MSWD}=0.70)$, whereas 13 points from sample DB77 yield an age of $300.3 \pm 4.8 \mathrm{Ma}(\mathrm{MSWD}=0.77)$. All three ages overlap within errors at ca. $300 \mathrm{Ma}$, in keeping with field relationships; they are interpreted as the crystallization time of the magmas.

Zircons from Sassello gneiss sample DB30 are similar to those of the Matorello granodiorite in all respects. Sixteen measurements define a weighed average ${ }^{206} \mathrm{~Pb} /{ }^{238} \mathrm{U}$ age of $296.7 \pm 3.9 \mathrm{Ma}(\mathrm{MSWD}=0.22)$, whereas two ablated cores yielded concordant ages at 540 and $455 \mathrm{Ma}$, respectively.

Sample DB44 from the Cocco granodiorite in the Maggia nappe hosts delicately zoned zircons like in the Matorello intrusion; no inherited core has been observed. 27 measurements define a weighed average ${ }^{206} \mathrm{~Pb} /{ }^{238} \mathrm{U}$ age of $307.8 \pm 7.0 \mathrm{Ma}$ (MSWD =0.14), interpreted as the crystallization age of the rock.

Zircon morphology of the nearby Rüscada leucogranite DB06 is very different. CL imaging reveals large zones with patchy or convolute zoning and a significant porosity, ascribed to the chemical abrasion of uranium-rich, metamictic zones (Fig. 5f). This structure either affects the periphery of the grain, preserving the central zone, or any part of the crystal. Some zircons do not show this kind of structure. Preserved parts usually display normal oscillatory or sector zoning in CL imaging, except one perfectly concordant core dated at 2,121 $\pm 25 \mathrm{Ma}$, which is homogeneously black. Preserved zircon parts give a wide range of concordant ages. Cores were dated at 2,121, 1,400, $765 \mathrm{Ma}$ and $537 \pm 15 \mathrm{Ma}$ (5 points, MSWD = 7; not shown), respectively, whereas 11 measurements of peripheral oscillatory growth zones define a weighed average ${ }^{206} \mathrm{~Pb} /{ }^{238} \mathrm{U}$ age of $300 \pm 12 \mathrm{Ma}(\mathrm{MSWD}=0.56)$. Ablation of five convolute porous zones yielded sub-concordant ages ranging from 267 to $222 \mathrm{Ma}$.

The orthogneiss block DB12 from the Tamier wildflysch yielded few zircons with classical CL oscillatory zoning and occasional patchy peripheral zones. No inherited core has been observed. Six analyses define a weighed average ${ }^{206} \mathrm{~Pb} /{ }^{238} \mathrm{U}$ age of $285.9 \pm 7.2 \mathrm{Ma}(\mathrm{MSWD}=1.7)$, interpreted as the crystallization time of the granite.

\subsection{Variscan lamprophyres}

The Laghetti lamprophyre DB76 supplied very few zircons with faint CL structures defining broad growth bands and a thin rim ascribed to metamorphic recrystallization. Only four concordant measurements were obtained; they define a weighed average ${ }^{206} \mathrm{~Pb} /{ }^{238} \mathrm{U}$ age of $298.7 \pm 7.9 \mathrm{Ma}$ $(\mathrm{MSWD}=0.53)$.

Zircons of the Sassello lamprophyre DB29 are more abundant and show classical CL structures with a few inherited cores and delicate oscillatory growth zones. Concordant core ages have been measured at 670, 590 and $440 \mathrm{Ma}$, respectively, whereas ablation of growth zones yielded 15 concordant points defining a weighed average ${ }^{206} \mathrm{~Pb} /{ }^{238} \mathrm{U}$ age of $296.9 \pm 4.6 \mathrm{Ma} \quad(\mathrm{MSWD}=0.69$ ), interpreted as the crystallization time of the dyke.

Tamier samples DB41 and DB42 supplied zircons with simple CL structure consisting of wide growth bands and sectors, local oscillatory zoning and thin metamorphic overgrowths. No inherited core has been observed. Seventeen measurements on DB41 zircons produce a weighed average ${ }^{206} \mathrm{~Pb} /{ }^{238} \mathrm{U}$ age of $287.8 \pm 6.5 \mathrm{Ma}$ (MSWD = 0.49 ) and 10 measurements on DB42 zircons an age of $286.5 \pm 5.3 \mathrm{Ma}(\mathrm{MSWD}=0.25$; Fig. 8).

\section{Discussion}

\subsection{Cambrian magmatism}

The ages of $544.1 \pm 4.5 \mathrm{Ma}$ and $533.5 \pm 7.4 \mathrm{Ma}$ obtained for the two metadiorites from the banded mafic complex of Alpe Scheggia overlap within errors at ca. 540 Ma and are interpreted as the crystallization time of this calc-alkaline magmatic suite (Fig. 6; Table 5). To our knowledge, these rocks are the oldest currently dated in an Alpine basement, apart from 870 Ma-old eclogite zircons from the Gotthard massif (Gebauer et al. 1988) and a diorite dated at $609 \pm 3 \mathrm{Ma}$ in the Silvretta Austroalpine nappe (Schaltegger et al. 1997). On the other hand, rocks indicative of contrasting geotectonic settings are recorded between 530 and $500 \mathrm{Ma}$ in various Alpine basements (see review of 
Schaltegger and Gebauer 1999). Evidence for a subducting oceanic crust in an active margin setting is documented by:

1. an oceanic plagiogranite in the Silvretta Austroalpine nappe dated at $532 \pm 30 \mathrm{Ma}$ (Müller et al. 1995);

2. a calc-alkaline gabbro-tonalite series in the same nappe dated at $523 \pm 3$ and $524 \pm 5 \mathrm{Ma}$, respectively (Schaltegger et al. 1997) and a calc-alkaline granite dated at $533 \pm 4 \mathrm{Ma}$ (Müller et al. 1995);

3. a $518 \pm 11$ Ma-old fractionated island-arc(?) gabbro from the mafic-ultramafic association of LoderioBiasca (Schaltegger et al. 2002), intercalated between the Simano and Leventina Lower Penninic nappes, i.e. close to the Sambuco nappe;

4. a mafic eclogite protolith dated at $528 \pm 6 \mathrm{Ma}$ (Gebauer 1996) from the Cima di Gagnone, a TAC unit linked to the Adula nappe (Berger et al. 2005).

Continental back-arc(?) rifting is documented by alkaline A-type granites in the Siviez-Mischabel nappe of the Briançonnais domain (Mt Pourri granite at $507 \pm 9 \mathrm{Ma}$, Guillot et al. 1991; Thyon granite at $500+3 /-4$ Ma; Bussy et al. 1996) and in the Austroalpine Silvretta nappe (526 $\pm 7 \mathrm{Ma}$, Müller et al. 1995). Finally, the $496 \pm 6$ Ma-old Chamrousse ophiolite in the Belledonne External massif might represent a back-arc ocean floor.

In the absence of a complete set of chemical and isotope data, we cannot discriminate between an island-arc and an active continental margin setting for the calc-alkaline series of Scheggia. In any case, its age of ca. $540 \mathrm{Ma}$ is in line with the general picture outlined above, which documents convergence tectonics, presumably in a peri-Gondwanan paleogeography (von Raumer et al. 2003). Interestingly, evidence for this Early Cambrian subduction-related magmatism is found in very different paleogeographic domains (i.e. External Massifs, North-Penninic and Austroalpine domains), which shows that paleogeography of the continental blocks was completely different during the Early Palaeozoic. Austroalpine and Helvetic/North-Penninic terranes might have been adjacent at that time, as suggested by some geodynamic reconstructions (e.g. von Raumer et al. 2003). According to Keller et al. (1980), the calcalkaline mafic intrusive suite of Albigia, located in the Antigorio nappe, is very similar to the Scheggia mafic complex. It could well be another witness of this Early Cambrian magmatic activity.

\subsection{Ordovician granites}

The magmatic interpretation of the $464.3 \pm 8.0 \mathrm{Ma}$ age calculated for the Massari metagranite DB25 is relatively straightforward, owing to the simple structure of the ablated CL domains and reproducibility of individual measurements.
Conversely, the crystallization age of the Sasso Nero augengneiss is difficult to establish, as illustrated by the internal age distribution of zircon L10 from sample DB61 (Fig. 5) and multiple age clusters at 630, 533, 473 and 416 Ma (Fig. 6). All ages older than $480 \mathrm{Ma}$ have been measured on more or less resorbed cores and are interpreted as inherited components (e.g. Fig. 5). The unusually high frequency and large size of inherited zircon cores, as well as their age diversity, suggest a metasedimentary magma source, in line with the peraluminous signature of this granite.

The two remaining age groups in sample DB61$473.4 \pm 7.5$ and $416 \pm 13 \mathrm{Ma}$-have been measured on oscillatory growth zones typical of magmatic crystallization; but the youngest ages always relate to peripheral zones with bright and faint CL structures. Our preferred interpretation is to consider the age of $473 \mathrm{Ma}$ as the time of crystallization of the Sasso Nero granite, which is supported by the $472 \pm 25 \mathrm{Ma}$ age of sample DB38 (see above). The younger dates would result from the partial resetting of the outermost growth zones, which experienced some $\mathrm{U}$ loss as suggested by their light CL color. The age of the disturbing event is not clear, it could be around $416 \mathrm{Ma}$ or even younger if we take into account the existence of ages down to $390-380 \mathrm{Ma}$. This interpretation is supported by the case of zircon L10 from sample DB61 (Fig. 5d), which yielded two contrasting ages for its apparently homogeneous peripheral bright growth zone, i.e. 519 and $381 \mathrm{Ma}$, respectively. The age of $519 \mathrm{Ma}$ is puzzling; it might either be a slightly disturbed $539 \pm 20 \mathrm{Ma}$ growth zone or a mixed age between the core and the disturbed growth zone.

Alternatively, we cannot totally exclude a magmatic event at $416 \pm 12 \mathrm{Ma}$, all older ages corresponding to inherited components. Such a young age would be unusual, as only one example is currently documented in the Alps: the $426 \pm 3$ Ma-old Kesch augengneiss in the Silvretta nappe (Poller et al. 1997). In summary, we interpret the crystallization age of the Sasso Nero granite to be $473.4 \pm 7.5 \mathrm{Ma}$, identical within errors to the age of $464.3 \pm 8.0 \mathrm{Ma}$ of the Massari granite, intruded in the Early Cambrian Scheggia mafic complex.

Ordovician magmatic rocks are ubiquitous in the Alps and it is no surprise that some occur in the Sambuco basement. A complete orogenic cycle is recorded in the Helvetic, Penninic, Austroalpine and Southern Alpine paleogeographic domains (see review of Schaltegger and Gebauer 1999). Pre-HP gabbros are dated at ca. $470 \mathrm{Ma}$, coeval with some granites in the Gotthard massif (472.2 $+7.6 /-3.2 \mathrm{Ma}$, Sergeev and Steiger 1996) and in the Briançonnais domain (Vanoise, $479 \pm 6 \mathrm{Ma}$; Bertrand and Leterrier 1997). HT barrovian metamorphism and migmatites are dated around $450 \mathrm{Ma}$ in the Aar and Gotthard 
massifs. Voluminous post-collisional to post-orogenic S- and I-type orthogneisses are found in almost all basement units, like in the External Crystalline Massifs (ca. 450-440 Ma, see Table 1 in von Raumer et al. 1999), the Lower Penninic nappes $(456 \pm 4 \mathrm{Ma}$, Monte Leone gneiss, Bergomi et al. 2007), the Briançonnais SiviezMischabel nappe (Ahorn gneiss, $455 \pm 2 \mathrm{Ma}$, Bussy unpublished data), and the Austroalpine Silvretta nappe (460-420 Ma, Poller et al. 1997).

In this framework, the ca. 470 Ma-old Massari and Sasso Nero S-type orthogneisses would correspond to precollisional granites, like the $478+8 /-4$ Ma granite of the Gotthard massif. This would be a rather unusual situation, as S-type granites are typically syn- or post-collisional in an orogenic cycle (e.g. Barbarin 1999). If our interpretation is correct, this would mean that these relatively small intrusions were not generated by large-scale melting of mid- to lower crustal lithologies, but would have acquired their peraluminous character by differentiation-in particular for the evolved and mildly peraluminous Massari granite - and/or contamination of originally metaluminous melts, which could explain the large proportion of unmelted zircon cores. Alternatively, if the Sasso Nero granite crystallized at $419 \pm 12 \mathrm{Ma}$, it would correspond to the latest magmatic episode of the Ordovician orogenic cycle.

\subsection{Variscan magmatism}

The three dated samples of the Matorello granodiorite, which display coeval field relationships, yield ages of $302.3 \pm 7.8, \quad 300.5 \pm 6.5$ and $300.3 \pm 4.8 \mathrm{Ma}$ (Fig. 7; Table 5). They overlap within errors at ca. $300 \mathrm{Ma}$, a date interpreted as the crystallization time of the intrusion. This age is similar to the ca. 300 Ma TIMS age proposed by Köppel et al. (1981), based on large zircon fractions. The $296.7 \pm 3.9 \mathrm{Ma}$ age of the Sassello orthogneiss, which is represented as disconnected from the main intrusion on the existing maps, demonstrates that it belongs to the Matorello. The extension of the Matorello magmatic body is probably much larger than believed until now and its limits need detailed remapping (only a minimal correction has been drawn on map Fig. 1).

Among the two lamprophyre dyke systems mapped by Ramsay and Allison (1979) in the Matorello granodiorite, one has been dated at $290.5 \pm 3.7 \mathrm{Ma}$ (Bussien et al. $2008 \mathrm{~b}$ ) and the other yields a poorly constrained age of $298.7 \pm 7.9 \mathrm{Ma}$ (4 data points); both are interpreted as magmatic ages (Table 5). The 296.9 \pm 4.6 Ma-old Sassello lamprophyre is coeval to the other ones within errors, as expected from the age similarity of the host granites.

The $307.8 \pm 7.0 \mathrm{Ma}$ age of the Cocco granodiorite in the Maggia nappe is interpreted as the time of its magmatic crystallization (Fig. 7; Table 5). This robust result based on 27 measurements shows that Cocco is contemporaneous to the Matorello granodiorite within errors, as expected from their striking petrographic similarity. The Rüscada leucogranite, intrusive into Cocco granodiorite, has an anatectic origin and is rich in inherited cores at 2,121, 1,400, 765 and $537 \mathrm{Ma}$. The few zircons preserved from metamictization yield a poorly constrained age of $300 \pm 12 \mathrm{Ma}$, interpreted as its crystallization time. These results are of importance, as they are much older than the determinations by Köppel et al. (1981) reported on the map of Berger and Mercolli (2006), which are $275 \mathrm{Ma}$ for Cocco and 240-250 Ma for Rüscada.

Variscan magmatism is documented in all the paleogeographic domains of the Alps. It is particularly well developed in the External Crystalline Massifs and in the Lower Penninic nappes, where it constitutes large granitic intrusions. This magmatic activity is characterized by short-lived pulses of specific magma types, which reflect the orogenic evolution of the belt from syn- to late- to postorogenic stages (Schaltegger 1997; Bussy et al. 2000; von Raumer and Bussy 2004). Three pulses have been outlined at 340-330, 310 and 300-290 Ma in the External Massifs. Granites are more or less potassic calc-alkaline or peraluminous and their $\mathrm{Fe} / \mathrm{Mg}$ ratio increases through time (Debon and Lemmet 1999).

In the Lower Penninic nappes, granites are essentially calc-alkaline. Available ages are the following, from deepest to highest units in the nappe pile. The Verampio granite is dated at $291 \pm 4 \mathrm{Ma}$ (IDTIMS, Bussy, unpubl. data) and $289 \pm 3 \mathrm{Ma}$ (SHRIMP, Bergomi et al. 2007). Four samples of the Antigorio pluton yielded SHRIMP ages of $296 \pm 2 \mathrm{Ma}$ for a tonalite, $294 \pm 5$ and $290 \pm 3 \mathrm{Ma}$ for granodiorites, and $289 \pm 4 \mathrm{Ma}$ for a granite (Bergomi et al. 2007). An age of $302 \pm 6$ Ma has been measured on an orthogneiss sample of the Monte Leone nappe (Bergomi et al. 2007). The Sambuco nappe being sandwiched between Antigorio and Monte Leone, the ca. $300 \mathrm{Ma}$ age of the Matorello granite and associated lamprophyres fits well this general framework.

The $307.8 \pm 7.0 \mathrm{Ma}$ Cocco granodiorite and $300 \pm 12$ Ma Rüscada leucogranite from the Maggia nappe are definitely not Permian, as admitted so far in the literature, but are contemporaneous with the Matorello pluton. This result has paleogeographic implications. Indeed, Berger et al. (2005) consider the Sambuco and Maggia nappes as belonging to different Mesozoic paleogeographic domains- "European" for Sambuco and "Briançonnais" for Maggia-separated by an oceanic basin, currently represented by the Someo suture zone (see above). Although the Briançonnais domain is defined according to Mesozoic stratigraphic criteria, its pre-Mesozoic basement is also distinct from the Helvetic basement. Its Late 
Paleozoic magmatic rocks are no older than ca. $270 \mathrm{Ma}$ (Randa granite $269 \pm 2 \mathrm{Ma}$, Bussy et al. 1996; Truzzo granite $268.0 \pm 0.4 \mathrm{Ma}$ and Roffna rhyolite $268.3 \pm$ $0.6 \mathrm{Ma}$, Marquer et al. 1998; Monte Rosa granite $270 \pm 4 \mathrm{Ma}$, Pawlig and Baumgartner 2001). Two older granitoid intrusions have been reported in a more western part of this domain in the Italian Alps, the Costa Citrin granite at $323 \pm 8 \mathrm{Ma}$ in the Zone Houillère Briançonnaise (Bertrand et al. 1998), and the Borda granodiorite at 300-294 Ma in the Ligurian Briançonnais (Gaggero et al. 2004).

This age distribution of the granites in the Briançonnais basement does not favour an affiliation of the Maggia nappe and its 310-300 Ma Cocco-Rüscada intrusions to this paleogeographic domain. Conversely, the close age and petrologic similarities between Cocco and Matorello granodiorites strongly suggest a paleogeographic proximity of the future Sambuco and Maggia nappes in Late Carboniferous times. Two main possibilities can be considered: (1) the Sambuco and Maggia gneissic bodies are parts of the same Alpine super-unit, as traditionally accepted (e.g. Spicher 1980; Steck 1998, 2008); or (2) Sambuco and Maggia form distinct nappes and their homelands were separated by a Mesozoic oceanic domain whose suture is materialized by the Someo TAC unit (Berger et al. 2005). In this case the similarity between the Cocco and Matorello plutons implies that no significant transcurrent movement occurred during the Mesozoic opening of this ocean nor during Alpine convergence, as no offset is observed between its margins. An intermediate possibility is that some sort of suture does separate these nappes but that it is not oceanic; there is also no transcurrent movement along this suture.

\subsection{Origin of the gneiss blocks of the Robièi wildflysch in the Antigorio nappe}

The two lamprophyre samples DB41 and DB42 intrusive in the Tamier orthogneiss blocks yielded similar ages of $287.8 \pm 6.5$ and $286.5 \pm 5.3 \mathrm{Ma}$, interpreted as magmatic (Fig. 8; Table 5). These results are in excellent agreement with the SHRIMP age of $284.8 \pm 1.7 \mathrm{Ma}$ measured on another lamprophyre dyke from the same locality (Bussien et al. 2008b). A lamprophyre from a block at the neighbouring Zött locality yielded a slightly older SHRIMP age of $290.0 \pm 1.3 \mathrm{Ma}$. This indicates that the lamprophyres contained in the blocks of the Robiè wildflysch emplaced over a period of several Ma.

On the basis of these preliminary data, of an additional LA-ICPMS age of $290.5 \pm 3.7 \mathrm{Ma}$ for a lamprophyre intruded into the Matorello granite and of striking geochemical similarities between the lamprophyres of the Sambuco nappe and of the Tamier blocks, Bussien et al. (2008b) concluded that the probable source of the gneiss blocks was the frontal part of the Sambuco nappe at the time of closure of the Antigorio-Teggiolo sedimentary basin. However Matasci et al. (2010) suggest that the source is more probably an unknown territory with a Paleozoic basement similar to the Sambuco basement, situated between the Antigorio and Sambuco nappes, because of the absence in the wildflysch of blocks typical of the very specific Sambuco sedimentary cover. This suggestion is not contradicted by the $285.9 \pm 7.2 \mathrm{Ma}$ age of the Tamier orthogneiss block DB12, significantly younger than the other Variscan granites dated in this study. Before any final conclusion could be drawn, more orthogneiss blocks should be dated to duplicate the $286 \mathrm{Ma}$ age of sample DB12.

\subsection{Inherited zircon components in the dated magmatic rocks}

Concordant ages of inherited zircon cores in the Ordovician granites have been measured at 2,730, 2,250, 1,780, $1,650,1,075,1,000,880,730,600-640$ and $540 \mathrm{Ma}$. This large range of data is mainly found in the many inherited zircon cores of the Sasso Nero augengneiss, whose peraluminous character suggests assimilation of metasedimentary materials. $540 \mathrm{Ma}$ is reminiscent of the Scheggia calc-alkaline complex, whereas 600-640 Ma ages are well-known inherited components of so-called Pan-African origin in Variscan and Ordovician granites and metasediments of the External Crystalline Massifs (Gebauer 1993). According to this author, ages cluster at 2.6, 2.1, 1.0 and $0.65 \mathrm{Ga}$ for zircons from a paragneiss of the Gotthard massif and recent river sand from the Po delta. Bertrand et al. (2000) have dated detrital zircons from micaschists of the "Série Satinée" in the Belledonne External massif. They obtained old ages at 3.4, 3.1, $2 \mathrm{Ga}$; Grenvillian ages at ca. 1,000-800 Ma; and a group of Pan-African zircons clustering at $594 \pm 36 \mathrm{Ma}$. In a more distant area, metasediments of the NW Variscan Iberian belt yielded various Precambrian age clusters at 2.8-2.5 Ga, 2-1.8 Ga, $1.2-0.9 \mathrm{Ga}$ and $800-640 \mathrm{Ma}$ (Martinez Catalan et al. 2008), all ascribed to detrital zircons from the $\mathrm{W}$ African craton of Gondwana. In conclusion, the inherited zircons of the Sambuco orthogneisses are typical of Gondwana-derived sources, in agreement with current paleogeographic reconstructions (e.g. von Raumer et al. 2003).

Paragneiss sample DB04 from Lake Zött yielded concordant zircon ages at 2,400, 1,600, 620 and $480 \mathrm{Ma}$. The last age is typical of Ordovician orthogneisses, and establishes a maximum deposition time for the sediment. The other ages are again reminiscent of Gondwana-derived sources. 
The Variscan calc-alkaline granites contain very few inherited zircons of lower Paleozoic ages (540, 500 and $455 \mathrm{Ma}$ ), which could correspond to the Scheggia complex and to the Ordovician orthogneisses. Similarly, the many zircon cores hosted by the Rüscada anatectic leucogranite are dominantly contemporaneous to the Scheggia magmatic event at $537 \pm 15 \mathrm{Ma}$ with some older ages comparable to those obtained on inherited zircons from the Ordovician orthogneisses $(2,121,1,400$ and $765 \mathrm{Ma})$.

\section{Conclusion}

All the main magmatic events known in the Paleozoic basements of the Alps are recorded in the Sambuco nappe. The Sambuco and Maggia nappes host late Variscan calcalkaline granites, that fall in the same general age range that those of the External Massifs and the Lower Penninic nappes, although their ages of ca. 300 Ma seem to be older by $5-10 \mathrm{Ma}$ than the neighboring Verampio and Antigorio intrusions. Lamprophyres associated to the Matorello pluton are slightly younger. All are distinctly older than the granitic intrusions of the Briançonnais domain.

Besides the Variscan Matorello pluton, the Sambuco nappe records the two other main Paleozoic magmatic episodes known in the Alps. Ordovician orthogneisses dated at ca. $470 \mathrm{Ma}$ can be related to the $480-450 \mathrm{Ma}$ orogenic cycle documented in the nearby Gotthard massif, whereas the Scheggia calc-alkaline suite dated at $540 \mathrm{Ma}$ is a direct witness of subduction-related magmatism at the Precambrian-Cambrian boundary. The age and nature of these successive magmatic events, together with their inherited zircon content, are consistent with current paleogeographic reconstructions, which consider Alpine basement units as Gondwana-derived terranes.

The 300-310 Ma age of the Cocco and Rüscada granites from the Maggia nappe is significantly older than former data. The striking similarities in age and rock facies between the Cocco and Matorello plutons strongly suggest that the Sambuco and Maggia nappes were adjacent in Late Carboniferous times. If any oceanic basin was separating them in the Mesozoic (Berger et al. 2005), no significant transcurrent displacement occurred during opening and closure of this basin, as no offset is observed between them.

Acknowledgments We would like to thank M.-O. Diserens, A. Ulianov, J. Allibon and S. Skora for their technical support in the laboratories (SEM, LA-ICPMS and electron microprobe). We also thank L. Nicod and J.-C. Lavanchy for their help and investment in sample preparation and analytical support. We are indebted to P.-A. Wülser for his expertise and decisive help in the process of zircon extraction and to U. Schaltegger (Geneva) for his pertinent comments of an early version of the manuscript. We are also very grateful to
A. Berger (Copenhagen) and B. Cenki-Tok (Bern) for constructive reviews and to the Dipartimento del Territorio of Ticino for authorizing us to collect samples. Development of the LA-ICPMS dating facility in Lausanne has been financially supported by the Swiss National Science Foundation (SNSF), grant no. 200021-109587.

\section{References}

Barbarin, B. (1999). A review of the relationships between granitoid types, their origins and their geodynamic environments. Lithos, 46, 605-626.

Beltrando, M., Rubatto, D., Compagnoni, R., \& Lister, G. (2007). Was the Valaisan basin floored by oceanic crust? Evidence of Permian magmatism in the Versoyen unit (Valaisan domain, NW Alps). Ofioliti, 32, 85-99.

Berger, A., \& Mercolli, I. (2006). Tectonic and petrographic map of the central Lepontine Alps. In: Carta geologica speciale 127, 1:100,000. Wabern: Federal Office of Topography.

Berger, A., Mercolli, I., \& Engi, M. (2005). The central Lepontine Alps: Notes accompanying the tectonic and petrographic map sheet Sopra Ceneri $(1: 100,000)$. Schweizerische Mineralogische Petrographische Mitteilungen, 85, 109-146.

Bergomi, M., Tunesi, A., Shi, Y.-R., Colombo, A., \& Liu, D.-Y. (2007). SHRIMP II U/Pb geochronological constraints of preAlpine magmatism in the lower Penninic units of the Ossola Valley (Western Alps, Italy). Geophysical Research Abstracts 9, EGU Vienna.

Bertrand, J.-M., Guillot, F., Leterrier, J., Perruchot, M., Aillères, L., \& Macaudière, J. (1998). Granitoïdes de la zone houillère briançonnaise en Savoie et en Val d'Aoste (Alpes occidentales): Géologie et géochronologie U-Pb sur zircon. Geodinamica Acta, $11,33-49$

Bertrand, J.-M., \& Leterrier, J. (1997). Granitoïdes d'âge Paléozoïque inférieur dans le socle de Vanoise méridionale: Géochronologie $\mathrm{U}-\mathrm{Pb}$ du métagranite de l'Arpont (Alpes de Savoie, France). Comptes Rendus de l'Academie des Sciences (Paris), Series IIA, Earth and Planetary Science, 325, 839-844.

Bertrand, J.-M., Pidgeon, R. T., Leterrier, J., Guillot, F., Gasquet, D., \& Gattiglio, M. (2000). SHRIMP and IDTIMS U-Pb zircon ages of the pre-Alpine basement in the Internal Western Alps (Savoy and Piemont). Schweizerische Mineralogische Petrographische Mitteilungen, 80, 225-248.

Boynton, W. (1984). Geochemistry of the rare earth elements: Meteorite studies. In P. Henderson (Ed.), Rare earth element geochemistry (pp. 63-114). Amsterdam: Elsevier.

Buchmann, H. (1953). Geologie und Petrographie des oberen Maggia Tales zwischen Fusio und Broglio im NW-Tessin (117 p.). Dissertation Universität Basel.

Burckhardt, C.E., \& Günthert, A. (1957). Blatt Basodino. Geologischer Atlas Schweiz 1:25000 (Nr. 34). Schweizerische Geologische Kommission.

Bussien, D., Bussy, F., \& Chiaradia, M. (2008a). Growth mechanisms of the bimodal Matorello calc-alkaline pluton, central Swiss Alps. Geophysical Research Abstracts 10, EGU Vienna.

Bussien, D., Bussy, F., Masson, H., Magna, T., \& Rodionov, N. (2008b). Variscan lamprophyres in the lower Penninic domain (Central Alps): Age and tectonic significance. Bulletin de la Société Géologique de France, 179, 369-381.

Bussy, F., \& Cadoppi, P. (1996). U-Pb zircon dating of granitoids from the Dora-Maira massif (western Italian Alps). Schweizerische Mineralogische und Petrographische Mitteilungen, 76, 217-233.

Bussy, F., Derron, M., Jacquod, J., Thélin, P., \& Sartori, M. (1996). The 500 Ma-old Thyon metagranite: A new A-type granite 
occurrence in the penninic realm (Western Alps, Switzerland). European Journal of Mineralogy, 8, 565-575.

Bussy, F., Eichenberger, M., Giroud, N., Masson, H., Meilhac, C., \& Presniakov, S. (2005). Early Carboniferous age of the Versoyen magmatism and consequences: Non-existence of a "Valais ocean". Abstract Volume, 3rd Swiss Geosciences Meeting, Zürich, 58.

Bussy, F., Hernandez, J., \& von Raumer, J. (2000). Bimodal magmatism as a consequence of the post-collisional readjustment of the thickened Variscan continental lithosphere (Aiguilles RougesMont Blanc Massifs, Western Alps). Transactions of the Royal Society of Edinburgh: Earth Sciences, 91, 221-233.

Bussy, F., \& von Raumer, J. (1994). U-Pb geochronology of Palaeozoic magmatic events in the Mont-Blanc Crys-talline Massif, Western Alps. Schweizerische Mineralogische Petrographische Mitteilungen, 74, 514-515.

Capuzzo, N., \& Bussy, F. (2000). High-precision dating and origin of synsedimentary volcanism in the Late Carboniferous SalvanDorénaz basin (Aiguilles-Rouges Massif, Western Alps). Schweizerische Mineralogische Petrographische Mitteilungen, $80,147-168$

de La Roche, H., Leterrier, J., Grandclaude, P., \& Marchal, M. (1980). A classification of volcanic and plutonic rocks using R1-R2 diagrams and major element analyses: Its relationships with current nomenclature. Chemical Geology, 29, 183-210.

Debon, F., \& Lemmet, M. (1999). Evolution of Mg/Fe Ratios in Late Variscan Plutonic Rocks from the External Crystalline Massifs of the Alps (France, Italy, Switzerland). Journal of Petrology, 40, 1151-1185.

Délèze, J. (1999). Géologie et minéralogie de la région de la Cristallina (Pennique inférieur, $N W d u$ Tessin) (288p.). Diplôme de Géologue, Université de Lausanne (unpubl.).

Engi, M., Berger, A., \& Roselle, G. (2001). Role of the tectonic accretion channel in collisional orogeny. Geology, 29, 1143-1146.

Frost, B., Barnes, C., Collins, W., Arculus, R., Ellis, D., \& Frost, C. (2001). A geochemical classification for granitic rocks. Journal of Petrology, 42, 2033-2048.

Gaggero, L., Cortesogno, L., \& Bertrand, J.-M. (2004). The preNamurian basement of the Ligurian Alps: A review of the lithostratigraphy, pre-Alpine metamorphic evolution, and regional comparison. Periodico di Mineralogia, 73, 85-96.

Galli, A., Mancktelow, N., Reusser, E., \& Caddick, M. (2007). Structural geology and petrography of the Naret region (northern Valle Maggia, N. Ticino, Switzerland). Swiss Journal of Geosciences, 100, 53-70.

Gebauer, D. (1993). The pre-Alpine evolution of the continental crust of the Central Alps-An overview. In J. von Raumer \& F. Neubauer (Eds.), Pre-mesozoic geology in the Alps (pp. 93-117). Heidelberg: Springer.

Gebauer, D. (1996). A P-T-t path for an (ultra?-) high-pressure ultramafic/mafic rock-association and its felsic country-rocks based on SHRIMP-dating of magmatic and metamorphic zircon domains. Example: Alpe Arami (Central Swiss Alps). In: A. Basu., \& S. Hart (Eds.), Earth processes: Reading the isotopic code (Geophysical Monograph Series 95, 269-276). Washington: American Geophysical Union.

Gebauer, D., von Quadt, A., Compston, W., Williams, I. S., \& Grünenfelder, M. (1988). Archaean zircons in a retrograded, Caledonian eclogite of the Gotthard Massif (Central Alps, Switzerland). Schweizerische Mineralogische Petrographische Mitteilungen, 68, 485-490.

Genier, F., Bussy, F., Epard, J.-L., \& Baumgartner, L. (2008). Waterassisted migmatization of metagraywackes in a Variscan shear zone, Aiguilles-Rouges massif, western Alps. Lithos, 102, $575-597$.
Gromet, L., Haskin, L., Korotev, R., \& Dymek, R. (1984). The "North American Shale Composite": Its compilation, major and trace element characteristics. Geochimica and Cosmochimica Acta, 48, 2469-2482.

Grujic, D., \& Mancktelow, N. S. (1996). Structure of the northern Maggia and Lebendun nappes, Central Alps, Switzerland. Eclogae Geologicae Helvetiae, 89, 461-504.

Grütter, O., \& Preiswerk, H. (1936). Das Gebiet der penninischen Decken westlich des Ticino. In: P. Niggli, H. Preiswerk, O. Grütter, L. Bossard, \& E. Kündig (Eds.) Geologische Beschreibung der Tessiner Alpen zwischen Maggia- und Bleniotal, 71, pp. 1-30. Neue Folge: Beiträge zur Geologischen Karte der Schweiz.

Guillot, F., Liegeois, J.-P., \& Fabre, J. (1991). Upper Cambrian granophyre of Mount Pourri, Brianconnais Zone, Vanoise; first $\mathrm{U} / \mathrm{Pb}$ dating of zircon from the basement of the internal French Alps. Comptes Rendus de l'Académie des Sciences (Paris) 313, Serie II, 239-244.

Guillot, F., Schaltegger, U., Bertrand, J., Deloule, E., \& Baudin, T. (2002). Zircon U-Pb geochronology of Ordovician magmatism in the polycyclic Ruitor Massif (Internal W Alps). International Journal of Earth Sciences, 91, 964-978.

Günthert, A. W., Stern, W. B., \& Schwander, H. (1976). Isochemische Granitgneisbildung im Maggia-Lappen (Lepontin der Zentralalpen). Schweizerische Mineralogische und Petrographische Mitteilungen, 56, 105-143.

Günthert, A. W., Stern, W. B., \& Schwander, H. (1996). The polycyclic evolution of the Penninic Maggia nappe, Central Alps: A summary report. Schweizerische Mineralogische und Petrographische Mitteilungen, 76, 1-22.

Hafner, S., Günthert, A., Burckhardt, C.E., Steiger, R.H., Hansen, J.W., \& Niggli, C. R. (1975). Blatt 1251 Val Bedretto. Geologischer Atlas Schweiz 1:25 000 (Nr. 68). Schweizerische Geologische Kommission.

Hasler, P. (1949). Geologie und Petrographie der Sambuco-MassariGebirgsgruppe zwischen der oberen Valle Leventina und Valle Maggia im nördlichen Tessin. Schweizerische Mineralogische und Petrographische Mitteilungen, 29, 50-155.

Horn, I., Rudnick, R. L., \& McDonough, W. F. (2000). Precise elemental and isotope ratio determination by simultaneous solution nebulization and laser ablation-ICP-MS: Application to U-Pb geochronology. Chemical Geology, 164, 281-301.

Huber, M., Ramsay, J., \& Simpson, C. (1980). Deformation in the Maggia and Antigorio nappes, Lepontine Alps. Eclogae Geologicae Helvetiae, 73, 593-606.

Jammes, S., Manatschal, G., Lavier, L., \& Masini, E. (2009). Tectonosedimentary evolution related to extreme crustal thinnig ahead of a propagating ocean: Example of the western Pyrenees. Tectonics, 28, TC 4012.

Keller, F. (1968). Mineralparagenesen und Geologie der Campo Tencia-Pizzo Forno-Gebirgsgruppe. Beiträge zur Geologischen Karte der Schweiz, Neue Folge, 135, 71 p.

Keller, F., Wenk, E., Bianconi, F., \& Hasler, P. (1980). Foglio 1272 P. Campo Tencia. Atlante geologico Svizzera 1:25,000 (Nr. 73). Schweizerische Geologische Kommission.

Kerrich, R., Fyfe, W. S., Gorman, B. E., \& Allison, I. (1977). Local modification of rock chemistry by deformation. Contribution to Mineralogy and Petrology, 65, 183-190.

Köppel, V., Günthert, A., \& Grünenfelder, M. (1981). Patterns of $\mathrm{U}-\mathrm{Pb}$ zircon and monazite ages in polymetamorphic units of the Swiss Central Alps. Schweizerische Mineralogische und Petrographische Mitteilungen, 61, 97-119.

Kosler, J., Fonneland, H., Sylvester, P., Tubrett, M., \& Pedersen, R.-B. (2002). U-Pb dating of detrital zircons for sediment provenance studies-A comparison of laser ablation ICPMS and SIMS techniques. Chemical Geology, 182, 605-618. 
Liégeois, J., \& Duchesne, J. (1981). The Lac Cornu retrograded eclogites (Aiguilles Rouges Massif, Western Alps, France): Evidence of crustal origin and metasomatic alteration. Lithos, 14, 35-48.

Lodetti, F. (2001). Géologie et minéralogie de la région du Naret (Pennique inférieur, NW du Tessin). DEA Sciences de la Terre (unpubl.), Université de Lausanne, $173 \mathrm{p}$.

Ludwig, K. R. (2003). Isoplot/Ex 3.00, a geochronological toolkit for Microsoft Excel, 70 p. Berkeley Geochronology Center Special Publication 4.

Marquer, D., Challandes, N., \& Schaltegger, U. (1998). Early Permian magmatism in Briançonnais terranes: Truzzo granite and Roffna rhyolite (Eastern Penninic nappes, Swiss and Italian Alps). Schweizerische Mineralogische und Petrographische Mitteilungen, 78, 397-414.

Martinez Catalan, J.-R., Fernandez-Suarez, J., Meireles, C., Gonzalez Clavijo, E., Belousova, E., \& Saeed, A. (2008). U-Pb detrital zircon ages in synorogenic deposits of the NW Iberian Massif (Variscan Belt); interplay of Devonian-Carboniferous sedimentation and thrust tectonics. Journal of the Geological Society of London, 165, 687-698.

Masson, H. (2002). Ophiolites and other (ultra)basic rocks from the West-Central Alps: New data for a puzzle. Bulletin de la Société Vaudoise des Sciences Naturelles, 88, 263-276.

Masson, H., Bussy, F., Eichenberger, M., Giroud, N., Meilhac, C., \& Presniakov, S. (2008). Early Carboniferous age of the Versoyen ophiolites and consequences: Non-existence of a "Valais ocean" (Lower Penninic, Western Alps). Bulletin de la Société Géologique de France, 179, 337-355.

Matasci, B., Epard, J.-L., \& Masson, H. (2010). The Teggiolo zone: A key to the Helvetic-Penninic connection (stratigraphy and tectonics in the Val Bavona, Ticino, Central Alps). Swiss Journal of Geosciences.

Mattinson, J. (2005). Zircon U-Pb chemical abrasion ("CA-TIMS") method: Combined annealing and multi-step partial dissolution analysis for improved precision and accuracy of zircon ages. Chemical Geology, 220, 47-66.

Maxelon, M., \& Mancktelow, N. S. (2005). Three-dimensional geometry and tectonostratigraphy of the Pennine zone, Central Alps, Switzerland and Northern Italy. Earth-Sciences Reviews, $71,171-227$

Mohanty, S., \& Ramsay, J. (1994). Strain partitioning in ductile shear zones: An example from a Lower Pennine nappe of Switzerland. Journal of Structural Geology, 16, 663-676.

Müller, B., Klötzli, U. S., \& Flisch, M. (1995). U-Pb and Pb-Pb zircon dating of the older orthogneiss suite in the Silvretta nappe, eastern Alps: Cadomian magmatism in the upper Austro-Alpine realm. International Journal of Earth Sciences, 84, 457-465.

Nakamura, N. (1974). Determination of REE, Ba, Fe, Mg, Na and K in carbonaceous and ordinary chondrites. Geochimica and Cosmochimica Acta, 38, 757-775.

Pawlig, S., \& Baumgartner, L. (2001). Geochemistry of a talckyanite-chloritoid shear zone within the Monte Rosa granite, Val d'Ayas, Italy. Schweizerische Mineralogische und Petrographische Mitteilungen, 81, 329-346.

Péron-Pinvidic, G., \& Manatschal, G. (2009). The final rifting evolution at deep magma-poor passive margins from IberiaNewfoundland: A new point of view. International Journal of Earth Sciences, 98, 1581-1597.

Poller, U., Liebetrau, V., \& Todt, W. (1997). U-Pb single-zircon dating under cathodoluminescence control (CLC-method): Application to polymetamorphic orthogneisses. Chemical Geology, 139, 287-297.

Preiswerk, H. (1925). Tessinergneiss mit tektonischer Kartenskizze. Eclogae Geologicae Helvetiae, 19, 177-187.
Preiswerk, H. (1931). Der Quartzdiorit des Coccomassives (Zentrale Tessineralpen) und seine Beziehungen zum Verzascagneis. Schweizerische Mineralogische und Petrographische Mitteilungen, 11, 27-55.

Pupin, J.-P. (1980). Zircon and granite petrology. Contributions to Mineralogy and Petrology, 73, 207-220.

Ramsay, J., \& Allison, I. (1979). Structural analysis of shear zones in an alpinised Hercynian granite (Maggia Lappen, Pennine Zone, Central Alps). Schweizerische Mineralogische und Petrographische Mitteilungen, 59, 251-279.

Rock, N. (1991). Lamprophyres (p. 285). New York: Blackie.

Schaltegger, U. (1997). Magma pulses in the Central Variscan Belt: Episodic melt generation and emplacement during lithospheric thinning. Terra Nova, 9, 242-245.

Schaltegger, U., Abrecht, J., \& Corfu, F. (2003). The Ordovician orogeny in the Alpine basement: Constraints from geochronology and geochemistry in the Aar Massif (Central Alps). Schweizerische Mineralogische und Petrographische Mitteilungen, 83, 183-195.

Schaltegger, U., \& Gebauer, D. (1999). Pre-Alpine geochronology of the Central, Western and Southern Alps. Schweizerische Mineralogische und Petrographische Mitteilungen, 79, 79-87.

Schaltegger, U., Gebauer, D., \& von Quadt, A. (2002). The maficultramafic rock association of Loderio-Biasca (lower Pennine nappes, Ticino, Switzerland): Cambrian oceanic magmatism and its bearing on early Paleozoic paleogeography. Chemical Geology, 186, 265-279.

Schaltegger, U., Nägler, T. F., Corfu, F., Maggetti, M., Galetti, G., \& Stosch, H. G. (1997). A Cambrian island arc in the Silvretta nappe: Constraints from geochemistry and geochronology. Schweizerische Mineralogische und Petrographische Mitteilungen, 77, 337-350.

Schmid, S. M., Fügenschuh, B., Kissling, E., \& Schuster, R. (2004). Tectonic map of the Alps. Eclogae Geologicae Helvetiae, 97, 93-117.

Sergeev, S. A., Meier, M., \& Steiger, R. H. (1995). Improving the resoution of single-grain $\mathrm{U} / \mathrm{Pb}$ dating by use of zircon extracted from feldspar: Application to the Variscan magmatic cycle in the central Alps. Earth and Planetary Science Letters, 134, 37-51.

Sergeev, S., \& Steiger, R. (1996). New estimate of emplacement and source ages of the acid gneisses constituting the pre-Alpine basement: Single-zircon and zircon fragment $\mathrm{U} / \mathrm{Pb}$ dating. Schweizerische Mineralogische und Petrographische Mitteilungen, 76, 121-122.

Simpson, C. (1981). Ductile shear zones: A mechanism of rock deformation in the orthogneiss of the Maggia nappe, Ticino, Switzerland, 266 p. PhD thesis, ETH Zürich.

Simpson, C. (1982). The structure of the northern lobe of the Maggia Nappe, Ticino, Switzerland. Eclogae Geologicae Helvetiae, 75, 495-516.

Simpson, C. (1983). Strain and shape fabric variations associated with ductile shear zones. Journal of Structural Geology, 5, 61-72.

Sláma, J., Kosler, J., Condon, D., Crowley, J., Gerdes, A., Hanchar, J., et al. (2008). Plesovice zircon-A new natural reference material for $\mathrm{U}-\mathrm{Pb}$ and $\mathrm{Hf}$ isotopic microanalysis. Chemical Geology, 249, $1-35$.

Spicher, A. (1980). Tektonische Karte der Schweiz, 1: 500,000. Basel: Schweizerische Geologische Kommission.

Stampfli, G. (1993). Le Briançonnais, terrain exotique dans les Alpes? Eclogae Geologicae Helvetiae, 86, 1-45.

Steck, A. (1998). The Maggia cross-fold: An enigmatic structure of the Lower Penninic nappes of the Lepontine Alps. Eclogae Geologicae Helvetiae, 91, 333-343.

Steck, A. (2008). Tectonics of the Simplon massif and Lepontine gneiss dome: Deformation structures due to collision between 
the underthrusting European plate and the Adriatic indenter. Swiss Journal of Geosciences, 101, 515-546.

Steck, A., Bigioggero, B., Dal Piaz, G. V., Escher, A., Martinotti, G., \& Masson, H. (1999). Carte géologique des Alpes de Suisse occidentale, $1: 100000$, Carte géologique spéciale 123. Bern: Service Hydrologique et Géologique National.

Steiner, H. (1984a). Radiometrische Alterbestimmungen an Gesteinen der Maggia-Decke (Penninikum der Zentralalpen). Schweizerische Mineralogische und Petrographische Mitteilungen, 64, 227-259.

Steiner, H. (1984b). Mineralogische-petrographische, geochemische und isotopengeologische Untersuchungen an einem Meta-Lamprophyr und seinem granodioritischen Nebengestein (MatorelloGneis) aus der Maggia-Decke. Schweizerische Mineralogische und Petrographische Mitteilungen, 64, 261-271. von Raumer, J., Abrecht, J., Bussy, F., Lombardo, B., Ménot, R.-P., \& Schaltegger, U. (1999). The Palaeozoic metamorphic evolution of the Alpine External Massifs. Schweizerische Mineralogische und Petrographische Mitteilungen, 79, 5-22.

von Raumer, J., \& Bussy, F. (2004). Mont Blanc and Aiguilles Rouges, geology of their polymetamorphic basement (External Massifs, Western Alps, France-Switzerland). Mémoires de Géologie (Lausanne), 42, 204.

von Raumer, J., Stampfli, G., \& Bussy, F. (2003). Gondwana-derived microcontinents-The constituents of the Variscan and Alpine collisional orogens. Tectonophysics, 265, 7-22.

Wiedenbeck, M., Alle, P., Corfu, F., Griffin, W. L., Meier, M., Oberli, F., et al. (1995). Three natural zircon standards for U-Th-Pb, Lu-Hf, trace element and REE analyses. Geostandards Newsletter, $19,1-23$. 